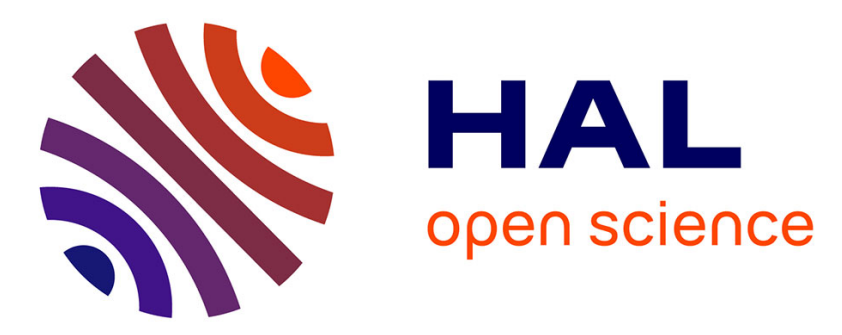

\title{
Effects of environmental antidepressants on colour change and locomotor behaviour in juvenile shore crabs, Carcinus maenas
}

Apolline Chabenat, Cécile Bellanger, Thomas Knigge

\section{- To cite this version:}

Apolline Chabenat, Cécile Bellanger, Thomas Knigge. Effects of environmental antidepressants on colour change and locomotor behaviour in juvenile shore crabs, Carcinus maenas. Aquatic Toxicology, 2021, 234, pp.105808. 10.1016/j.aquatox.2021.105808 . hal-03225142

HAL Id: hal-03225142

https://hal.science/hal-03225142

Submitted on 16 Jun 2021

HAL is a multi-disciplinary open access archive for the deposit and dissemination of scientific research documents, whether they are published or not. The documents may come from teaching and research institutions in France or abroad, or from public or private research centers.
L'archive ouverte pluridisciplinaire $\mathbf{H A L}$, est destinée au dépôt et à la diffusion de documents scientifiques de niveau recherche, publiés ou non, émanant des établissements d'enseignement et de recherche français ou étrangers, des laboratoires publics ou privés. 


\section{Highlights}

- Combination of fluoxetine and venlafaxine impaired colour change and locomotion in Carcinus maenas.

- Juvenile crabs exposed to fluoxetine displayed a transient effect on colour change.

- Juvenile crabs exposed to combined antidepressants were less efficient at adapting their colouration to their environment.

- Juvenile crabs exposed to combined antidepressants exhibited an increased locomotor activity. 


\title{
Effects of environmental antidepressants on colour change and locomotor
} behaviour in juvenile shore crabs, Carcinus maenas.

Apolline Chabenat ${ }^{1,2,3}$, Cécile Bellanger ${ }^{2,3}$, Thomas Knigge ${ }^{1 *}$

${ }^{1}$ NORMANDIE UNIV, UNILEHAVRE, FR CNRS 3730 SCALE, UMR-I02, Environmental Stress and Biomonitoring of Aquatic Environments (SEBIO), 76600 LE HAVRE, FRANCE

${ }^{2}$ NORMANDIE UNIV, UNICAEN, CNRS, EthoS (Éthologie animale et humaine) - UMR 6552, F-14000 CAEN, FRANCE

${ }^{3}$ UNIV RENNES, CNRS, EthoS (Éthologie animale et humaine) - UMR 6552, F-35000 RENNES, FRANCE

*Corresponding author: Thomas KNIGGE*

Unité Stress Environnementaux et Biosurveillance des milieux aquatiques, UFR Sciences et Techniques, Université Le Havre Normandie, 25 rue Philippe Lebon, 76063, Le Havre, France.

E-mail address: thomas.knigge@univ-lehavre.fr

\begin{abstract}
Juvenile crabs of Carcinus maenas thrive in coastal waters reputed to be the receptacle of continental pollution. Amongst the many pollutants encountered, antidepressants, such as fluoxetine (FLX) and venlafaxine (VEN), often detected at the $n g \cdot \mathrm{L}^{-1}$ range, are particularly worrying because of their action on the levels of monoamines, such as serotonin, norepinephrine and dopamine. In crustaceans, those monoamines are involved in colour change through their action on neuropeptide hormones. In addition, they are known to have a role in different behaviours, such as locomotion. Both colour change and locomotion are strategies used by juvenile crabs to hide and escape from predators. To investigate if the presence of antidepressants may alter behaviours of ecological importance, juvenile crabs were exposed to environmentally realistic concentrations of either $5 \mathrm{ng} \cdot \mathrm{L}^{-1}$ of FLX alone or in combination with VEN at $5 \mathrm{ng} \cdot \mathrm{L}^{-1}$. The ability to change colour depending on the environment and the locomotor activity of juvenile crabs were monitored weekly over 25 days. Animals exposed to antidepressants displayed a different pattern of colour change than the controls, especially those exposed to the combination of FLX and VEN at $5 \mathrm{ng} \cdot \mathrm{L}^{-1}$ each, and were less efficient to adapt to
\end{abstract}


their environment, i.e., they were not as pale and not as dark as control or crabs exposed to FLX at $5 \mathrm{ng} \cdot \mathrm{L}^{-1}$. Moreover, juvenile crabs exposed to the combination of antidepressants exhibited an enhanced locomotor activity throughout the exposure period with a higher velocity and distance moved as well as more time spend moving. The alteration of cryptic behaviours, such as colour change and locomotion by antidepressants persistently present in marine environment at low concentrations may have an impact on the survival of juvenile of $C$. maenas on the long term.

\section{Introduction}

Camouflage is defined as "body colours and patterns and other morphological adaptations that decrease the probability that an animal will be detected or recognized" (Merilaita et al., 2017). Camouflage may also comprise complex behavioural choices (Stevens and Ruxton, 2019), such as actively choosing substrates depending on their colour, called 'background matching' (Marshall et al., 2016; Tyrie et al., 2015), moving without rising suspicion of predators (or preys) by mimicking elements of the environment, i.e., matching environmental motion (Bian et al. 2016), or simply remaining immobile (Caro, 2005; Lindberg, 1980). To conceal themselves in their environment, some animals are capable of rapid colour changes - within hours to days - in order to adapt to the background has been described for shrimps (Siegenthaler et al., 2018), juvenile shore crabs (Stevens et al., 2014a) and fish (Sugimoto, 2002). These rapid colour changes are called 'physiological colour change'. They involve pigments contained in specialised cells, named chromatophores. These pigments can reversibly disperse or concentrate/aggregate (Fingerman, 1965). Slower and long-lasting colour changes, named 'morphological colour change', involve structural changes, for instance the density of chromatophores, or pigments embedded in the cuticle of arthropods (Umbers et al., 2014). In crustaceans, physiological and morphological colour changes can overlap, allowing animals to blend into their environment over different time scales (Fingerman, 1985). In the green shore crab, Carcinus maenas, colour change is particularly visible during the early life stages (Stevens et al. 2014a; 2014b), whilst the cuticle is still translucent. Powell (1962a) identified three types of monochromatic chromatophores in C. maenas containing black, white and red pigments. In addition, recent evidence points to the existence of yellow pigments (Nery and Castrucci, 2002; Stevens, 2016). Therefore, juvenile crabs can darken or brighten within hours (Stevens et al. $2014 \mathrm{~b}$ ) and display different colours and various patterns on their carapace and legs (Stevens et 
al., 2014a, 2014b). These may range from uniform to disruptive colouration. Both, physiological and morphological colour changes allow the crabs to perfectly camouflage themselves in the heterogeneous and variable microhabitats of the upper intertidal zone where the juveniles thrive (Fig. 1).

Both, rapid and slower, i.e., physiological and morphological, colour changes in crustaceans are triggered by hormonal neuropeptides that either act on the dispersion or concentration of pigments, or on moulting and tanning. The chromatophorotropins 'Red-Pigment Concentrating Hormone' (RPCH) and 'Pigment Dispersing Hormone' (PDH), the latter of which comes in two isoforms, regulate physiological colour changes in decapod crustaceans (Christie et al., 2010; Fingerman et al., 1998; Powell, 1962b). The RPCH induces pigment concentration notably in erythrophores, but may also act on leucophores, melanophores and xanthophores, whereas PDH appears to trigger pigment dispersion in all types of chromatophores (reviewed in Rao, 2001). Putatively, other neuropeptides, such as corazonin (Porras et al., 2003), or crustacean cardioactive peptide (Nery et al., 1999) may be involved in rapid colour change as well. Upstream, those hormones are influenced by monoamines, such as serotonin (5hydroxytryptamine, 5-HT), norepinephrine (NE) — or the chemically similar octopamine - and dopamine (DA). The secretion of PDH is known to be stimulated by 5-HT and NE (Rao and Fingerman, 1970; Hanumante and Fingerman, 1981; Fingerman, 1985), whereas DA stimulates the release of RPCH (Fingerman, 1985).

The monoamines 5-HT, NE and DA are also known to have roles in diverse behaviours of crustaceans, such as agonistic behaviour (Sneddon et al., 2000 ; Tierney and Mangiamele, 2001), phototactic behaviour (McPhee and Wilkens, 1989), anxiety-like behaviour (Fossat et al., 2014), and locomotion (Barthe et al., 1989; McPhee and Wilkens, 1989; Peeke et al., 2000). The latter appears to be essential for the survival of juvenile crabs as it allows them to escape and to repair to locations with an appropriate background that matches their body colouration. Indeed, background matching is very efficient as long as the animals stay still. Nevertheless, after a short time juvenile crabs usually attempt to flee, so as to avoid the field of vision of their predators (Siegenthaler et al., 2018). This requires locomotor activity, hence providing a link between camouflage and locomotion. As stated above, monoamines can have an impact on behavioural traits where locomotion is involved. McPhee and Wilkens (1989) have demonstrated that elevated 5-HT-levels increased and triggered locomotion in random directions. Thus, any change 
in the levels of monoamines, either by modulation of their synthesis, release, action or reuptake will impact the neurosecretory release of peptide hormones or directly act on motor control centres. As a matter of consequence, colour change and/or locomotor behaviour of juvenile crabs may both be modified by antidepressants, which is likely to affect camouflage and cryptic behaviour and potentially will imperil their survival.

Various pollutants are released into the coastal areas where the juvenile crabs develop. Several compounds may interfere with the synthesis, release and the regulation of monoamine concentrations in non-target organisms and, in turn, may affect camouflage and cause alterations of behaviour. Of particular concern are antidepressants, because they are specifically designed to act on serotoninergic and norepinergic systems (Mezzelani et al., 2018). Given that their prescription is still rising (OECD Health Statistics 2019), considerable amounts of residues are being released each day through human excretion or disposal of unused and expired pills in toilets (Jones et al., 2001), and are only inefficiently removed by wastewater treatment plants (Bueno et al., 2012; Schlüsener et al., 2015). Notwithstanding, concentrations of individual antidepressants were reported to be in the low $\mathrm{ng} \cdot \mathrm{L}^{-1}$ range (Klosterhaus et al., 2013; Meador et al., 2016; Minguez et al., 2016). It is, therefore, unclear whether antidepressants can actually affect wildlife (Sumpter et al., 2014). As most antidepressants act on the regulation of monoamine levels, i.e., have similar modes of action, the cumulated concentrations of these compounds should be much more meaningful for exposure studies than exposures to single antidepressants. Indeed, cumulated amounts of different antidepressants combine to significant concentrations in fresh and marine waters (Gonzalez-Rey et al., 2015; Meador et al., 2016; Metcalfe et al., 2010; Paíga et al., 2016; Rúa-Gómez and Püttmann, 2012). Amongst these, we focused on the two most prescribed antidepressants, the Selective Serotonin Reuptake Inhibitor (SSRI) fluoxetine (FLX) and the Serotonin Norepinephrine Reuptake Inhibitor (SNRI) venlafaxine (VEN) (Fong and Ford, 2014), which were detected at concentrations up to $0.3 \mathrm{ng} \cdot \mathrm{L}^{-}$ ${ }^{1}$ for FLX and $1.3 \mathrm{ng} \cdot \mathrm{L}^{-1}$ for VEN by Minguez et al. (2016) in Northwestern coastal waters of France. Both molecules are designed to act at low doses (Broekkamp et al., 1995), thus raising concern about their potential sub-lethal effects in non-target organisms, such as crabs. Because FLX was the first SSRI distributed at the end of the 1980's, many studies were dedicated to the effects of FLX alone. We, therefore, used FLX as single reference antidepressant in order to provide a link to the results from earlier work. 
In this study, we tested the hypothesis that cumulated environmental concentrations of some of the most prominent antidepressants can effectively modulate cryptic behaviour comprising colour change and locomotion in C. maenas. Over the last decade, several studies investigated the effects of antidepressants on different behavioural traits in aquatic species and highlighted impairments of predatory behaviour (Bisesi et al., 2014; Mennigen et al., 2010), maturation and learning processes (Chabenat et al., 2019; Di Poi et al., 2013), or reproductive behaviour (Campos et al., 2016). Even if behaviour becomes increasingly important in ecotoxicological research (Brodin et al., 2014), little attention has been given to the effect of pollutants on camouflage associated behaviours, such as colour change. Some studies have shown that colour change was affected by the presence of FLX or VEN in juvenile cuttlefish (Bidel et al., 2016a, 2016b; Di Poi et al., 2014) and in sand shrimp (Ford and Feuerhelm, 2020). A number of studies have investigated the effects of pollutants such as PCB, naphthalene or cadmium on colour change in crustaceans (Fingerman et al., 1998). Mesquita et al. (2011) have demonstrated an effect of FLX on locomotor behaviour in C. maenas, but at very high concentrations, ranging from 120 to $750 \mu \mathrm{g} \cdot \mathrm{L}^{-1}$. Another study reported increased locomotor behaviour in Hemigrapsus oregonensis following exposure to $30 \mathrm{ng} \cdot \mathrm{L}^{-1}$ FLX (Peters et al., 2017). Effects of FLX and VEN on locomotion were also observed in marine snails, in which locomotor activity was either reduced or increased (Fong et al., 2015). To date, only few studies considered cumulated concentrations of more than one antidepressant, which, however, represents a more environmentally realistic exposure scenario. Previous studies suggest pronounced effects on learning processes related to sand-digging behaviour in juvenile cuttlefish, or the modification of sand-digging behaviour in juvenile shore crabs (Chabenat et al., 2019), on predatory behaviour in striped sea bass (Bisesi et al., 2016) and on predator avoidance behaviour of larval fathead minnows (Painter et al., 2009) when different antidepressant were combined.

To test the hypothesis, this study examines - for the first time - the effect of two cumulated antidepressants on colour change and locomotor behaviour in juvenile C. maenas. Any modification of colour change ability or locomotion may be critical for the survival of the juvenile crabs. Hence, this study focuses on the effect of environmentally realistic exposure to antidepressants on fundamental behavioural endpoints in juvenile shore crabs.

\section{Materials \& Methods}




\subsection{Animal collection, housing and experimental conditions}

Juvenile green shore crabs (C. maenas, L. 1758) were collected by hand on the rocky shore of Yport, France (between N 49 43' 47, E $0^{\circ} 16^{\prime} 3$ and N 49 44' 25, E $0^{\circ} 18^{\prime} 47$ ) on the upper intertidal were the smallest animals reside. The intertidal foreshore of Yport is a heterogeneous habitat composed of chalk and flintstone with several dispatched areas of sand separated by small to large shingles covered with kelp as well as green or red algae. Correspondingly, the crabs collected along this shoreline were quite heterogeneous, displaying various patterns from uniform to highly disruptive (Fig. 1). The crabs ranged from 9-20 $\mathrm{mm}$ cephalothorax width. Although they may have strongly pigmented spots (Fig. 1), the cuticle of juveniles of this size is sufficiently thin and semi-transparent for colour changes by the subjacent chromatophores to be detectable. The resulting brightening or darkening also intensifies, or attenuates disruptive colouration (Detto et al., 2008). 


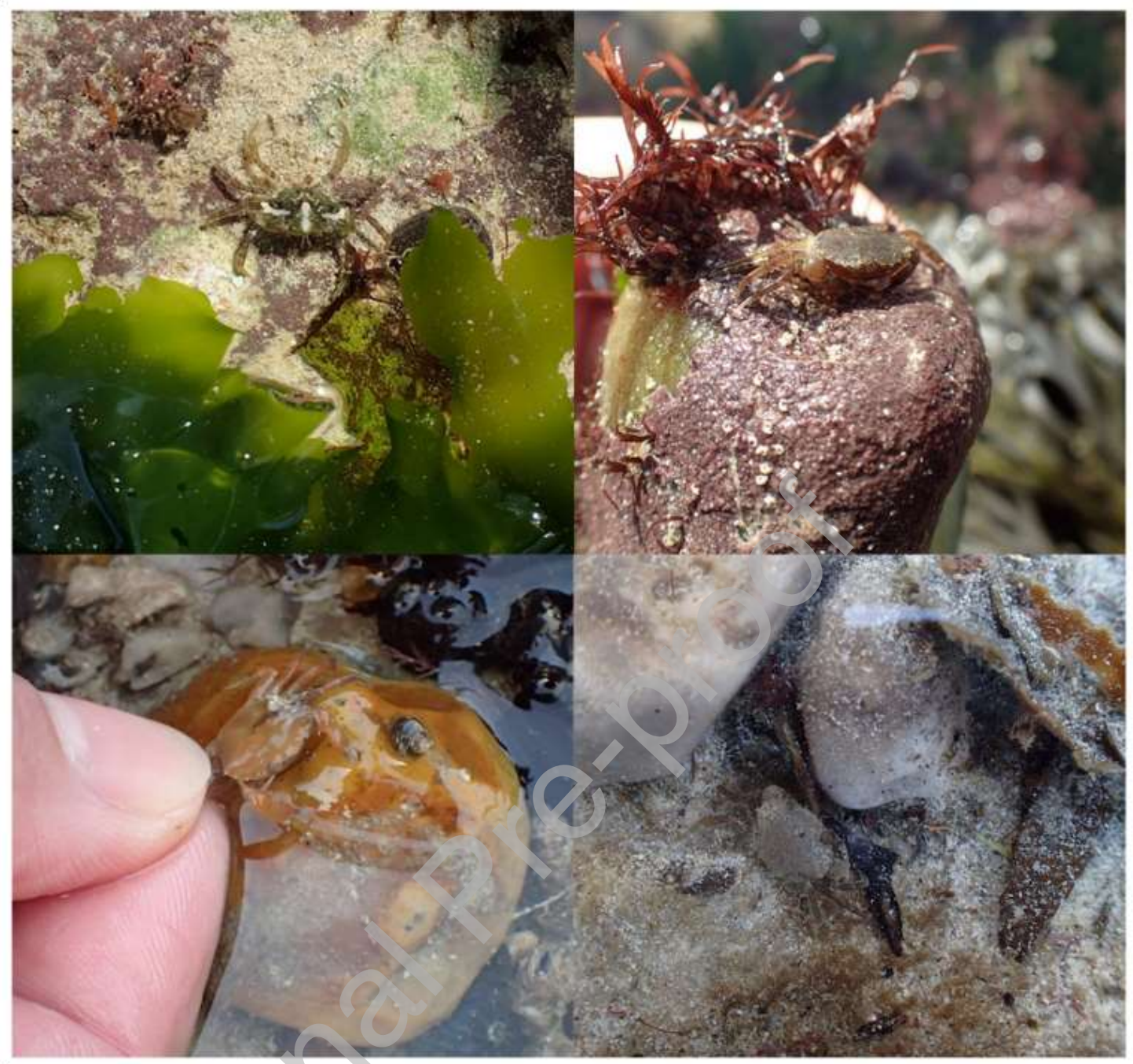

Figure 1. Photography of juvenile crabs, Carcinus maenas, that exhibit background matching in various micro-habitats of the intertidal foreshore of Yport (France) with green and red algae as well as sandy and rocky substrates.

Animals were transferred to the laboratory and separated into different tanks according to their size to avoid cannibalism (density $=15 \pm 5 \mathrm{crabs} / \mathrm{tank}$ of $20 \mathrm{~L}$ ). The animals were kept in a closed-loop system with filtered and oxygenated artificial seawater (ASW) made from Marine SeaSalt (Tetra, Melle, Germany) with dechlorinated tap water at a salinity of 35 PSU. Temperature and photoperiod were maintained at $15 \pm 1^{\circ} \mathrm{C}$ and $12 \mathrm{~h}$ light : $12 \mathrm{~h}$ dark $(8$ a.m. to 8 p.m.), respectively. Animals were fed once a day at 9 a.m. with pieces of frozen seabass filet (Dicentrarchus labrax) over the entire experiment. Animals were kept in those conditions for 
eight weeks in order to acclimate and to override their endogenous locomotor rhythmicity (Naylor, 1985; Webb, 1983).

Taking into account the variability among crabs (Stevens et al., 2014a), we evenly distributed the crabs to the different test conditions so as to comprise the varying sizes and patterns as good as possible. It was assured that no statistically significant difference in size distribution occurred between the groups (at d-9, Kruskal-Wallis, p=0.59). For the patterns, a 'benchmark week' was included in which the crabs underwent testing under control condition, i.e., in ASW only (Fig. 2), thus serving as their own individual references. To this end, juvenile crabs were isolated in 250 $\mathrm{mL}$ glass beakers ( $66 \mathrm{~cm}$, height $10 \mathrm{~cm}$ ) containing $200 \mathrm{~mL}$ of ASW during 8 days (i.e., from day -8 to day 0 ). Each crab was submitted to the behavioural tests as described below, in order to provide reference values for each individual crab (Fig. 2). These reference data were then used to normalise the test data of each crab from all treatment groups at all time points of exposure so as to determine the potential effect of antidepressants by minimising individual variability.

After the benchmark week, i.e., at day 0, juvenile crabs were exposed individually to either (i) ASW (control), or (ii) ASW with $5 \mathrm{ng} \cdot \mathrm{L}^{-1}$ of FLX alone (FLX5), or (iii) ASW with $5 \mathrm{ng} \cdot \mathrm{L}^{-1}$ of FLX and $5 \mathrm{ng} \cdot \mathrm{L}^{-1}$ of VEN (FLXVEN5). Juvenile crabs of each treatment group were submitted to the behavioural tests, i.e., colour change and locomotor behaviour once a week so as to obtain four time points over a period of 25 days (Fig. 2), using the same glass beakers as described above, henceforth designated 'home tanks'.

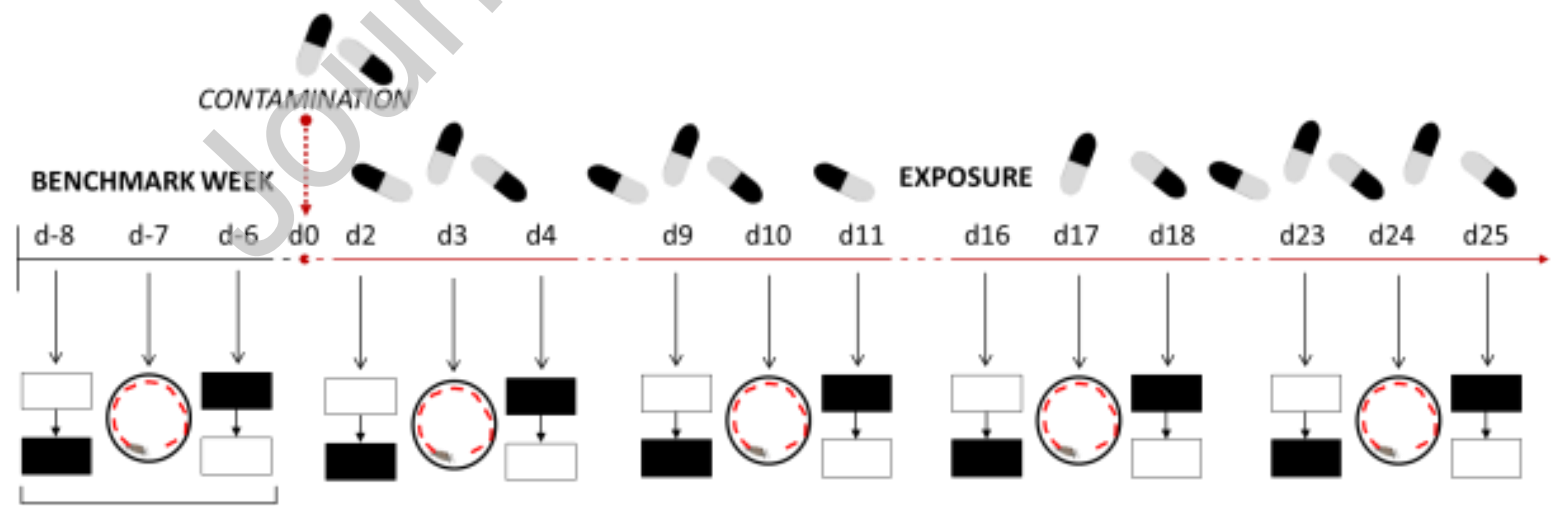

collect reference data
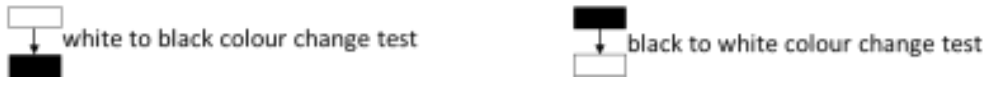

openfield test 
Figure 2. Chronology of behavioural tests. Following a benchmark week providing individual reference data for each individual and test, i.e., colour change (white to black and black to white) and locomotor behaviour (openfield), for all juvenile crabs. The contamination commenced at day $0(\mathrm{~d} 0)$ for 25 days. Behavioural tests began at day $2(\mathrm{~d} 2)$ and were repeated every week over a period of 25 days.

\subsection{Chemical treatment}

Stock solutions at $10 \mu \mathrm{g} \cdot \mathrm{L}^{-1}$ of either FLX hydrochloride (CAS 56296-78-7, Sigma Aldrich, St. Louis, USA) or VEN hydrochloride (CAS 99300-78-4, Sigma Aldrich) dissolved in distilled water were prepared and aliquots kept at $-80^{\circ} \mathrm{C}$. For $4 \mathrm{~L}$ of final aqueous media, $2 \mathrm{~mL}$ of FLX for the condition FLX at $5 \mathrm{ng} \cdot \mathrm{L}^{-1}$ and $2 \mathrm{~mL}$ of each FLX and VEN for the condition with FLX at 5 $\mathrm{ng} \cdot \mathrm{L}^{-1}+\mathrm{VEN}$ at $5 \mathrm{ng} \cdot \mathrm{L}^{-1}$ were added daily to ASW together with a complete water renewal, so as to obtain final concentrations of either $5 \mathrm{ng} \cdot \mathrm{L}^{-1}$ of FLX alone (FLX5), or $5 \mathrm{ng} \cdot \mathrm{L}^{-1}$ of FLX and $5 \mathrm{ng} \cdot \mathrm{L}^{-1}$ of VEN in combination (FLXVEN5), respectively. The concentrations were chosen according to concentrations detected along the Normandy coast, i.e., $0.3 \mathrm{ng} \cdot \mathrm{L}^{-1}$ for FLX and 1.3 $\mathrm{ng} \cdot \mathrm{L}^{-1}$ for VEN (Minguez et al., 2016).

\subsection{Behavioural tests}

\subsubsection{Colour change test on opposite background}

Crabs were placed, within their home tanks, in either a white or a black environment composed of painted Plexiglas for underneath and laminated paper for the sides. After 21 hours, each individual crab was photographed before being placed in the opposite colour environment, i.e., black to white, or white to black, for 2 hours, after which a second picture was taken (Fig. 3). All images were taken in a black tent (Neewer ${ }^{\circledR}$, Guangdong, China) equipped with a circular LED lamp $\left(\right.$ Neewer $\left.{ }^{\circledR}\right)$ in order to have a homogeneous light source. Photography was carried out with a Stylus Tough TG-4 digital camera (Olympus, Tokyo, Japan) against a grey medium background (Lastolite, Manfrotto, Cassola, Italy). The images were analysed a posteriori using Image $^{\odot}$ (Bethesda, Maryland, USA) in order to obtain: (i) the absolute colour change, (ii) the per cent colour change and (iii) the normalised colour change:

(i) Absolute colour change is defined by the Mean Grey Values (MGV), corresponding to the sum of the grey values of all the pixels in the selected area divided by the 
number of pixels, i.e., the average brightness/darkness in the selected carapace area. The MGV for each crab of each treatment group at each time point in either of the environments (black or white) is obtained after the contours of the crab's carapace were drawn manually using Image ${ }^{\odot}$. A MGV of 0 corresponds to absolute black, whereas a MGV of 255 corresponds to absolute white (Fig. 3.A). These data were used to calculate both (ii) per cent colour change and (iii) normalised colour change.

(ii) Per cent colour change is defined as the percentage of colour change, i.e., amplitude of absolute colour change between the two opposite environments (black or white). It is calculated at each time point from $\mathrm{MGVs}$ at $21 \mathrm{~h}$ and $2 \mathrm{~h}: \% \mathrm{cc}=\left[\left(\mathrm{MGV}_{21 \mathrm{~h}}-\right.\right.$ $\left.\left.\mathrm{MGV}_{2 \mathrm{~h}}\right) / \mathrm{MGV}_{21 \mathrm{~h}}\right] \times 100($ Fig. 3.B).

(iii) Normalised colour change, designated $\Delta \mathrm{cc}$ and expressed as fold change, is defined as the difference between $\mathrm{MGV}$ at $21 \mathrm{~h}$ and at $2 \mathrm{~h}\left(\mathrm{MGV}_{21 \mathrm{~h}}-\mathrm{MGV}_{2 \mathrm{~h}}\right)$, at each time point normalised with the reference data of each crab (benchmark), and expressed as fold-change relative to $\Delta \mathrm{cc}_{\text {benchmark week, }}$ i.e., $\Delta \mathrm{cc}_{\text {fold-change }}=\Delta \mathrm{cc}_{\text {experimental time point }} /$

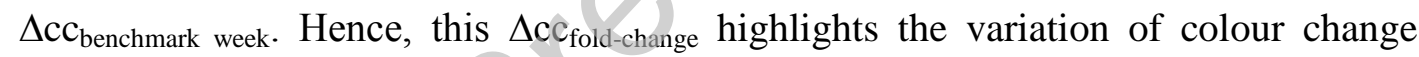
during the experimental time course relative to the benchmark value. After normalisation, a fold-change of relative colour change equal to 1 means that there was no difference between $\Delta c c_{\text {experimental time point }}$ and $\Delta \mathrm{cc}_{\text {benchmark week, whereas inferior or }}$ superior to 1 means a decrease or an increase of the capacity to brighten or darken respectively, depending on the condition (Fig. 3.C). 
A. Absolute colour change (MGV)

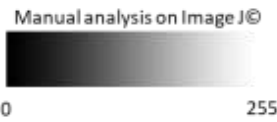

B. Percent colour change (\%cc)

\section{Normalised colour change} $\left(\Delta \mathrm{cc}_{\text {fold-change }}\right)$

$>1$, increase of colour change amplitude

$=1$, no modification of amplitude colour change

$<1$, decrease of colour change amplitude
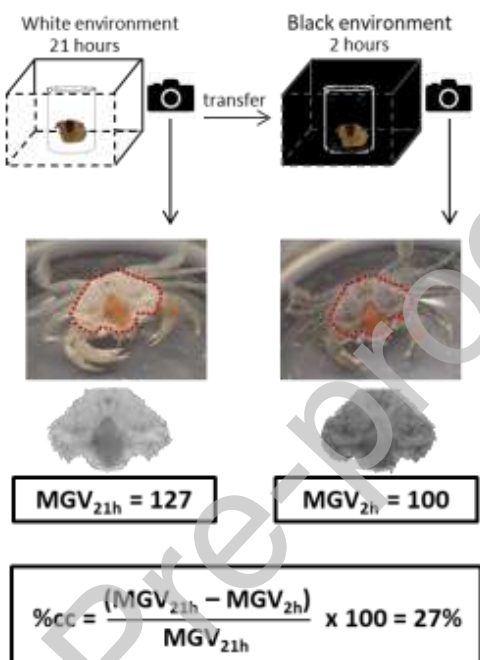

$$
\Delta C C_{\text {erperimental time point }}=M V_{21 h}-M G V_{2 h}=27
$$

$\Delta C C_{\text {benchmark week }}=22$

$$
\Delta \mathrm{CC}_{\text {fold change }}=\frac{\Delta \mathrm{CC}_{\text {experimental point }}}{\Delta \mathrm{CC}_{\text {benchmark week }}}=1.23
$$

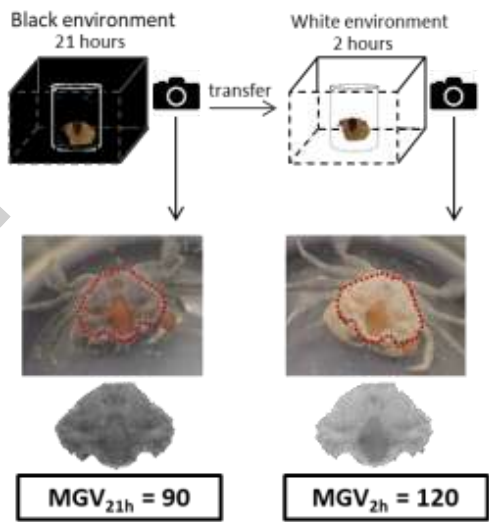

$$
\% c c=\frac{\left(M_{21 h}-M G V_{2 h}\right)}{M G V_{21 h}} \times 100=-33 \%
$$

$\Delta C C_{\text {experimental time point }}=M V_{21 h}-M G V_{2 h}=-30$

$\Delta \mathrm{CC}_{\text {benchmark week }}=-29$

$\Delta \mathrm{CC}_{\text {fold change }}=\frac{\Delta \mathrm{Cc}_{\text {experimental point }}}{\Delta \mathrm{Cc}_{\text {benchmark week }}}=1.03$

Figure 3. Procedure for colour change test: Crabs are placed with their home tanks in either a white or black environment for 21 hours. A first picture is taken before the crab is transferred to the opposite environment, either black or white, for 2 hours, after which a second picture is taken. Both pictures are analysed in Image ${ }^{\odot}$ to obtain the absolute colour change and to calculate the per cent and normalised colour change. 


\subsubsection{Locomotor behaviour}

Crabs were gently transferred from their tanks to the test arena placed under a black tent $\left(\right.$ Neewer $\left.^{\circledR}\right)$ to avoid any external stimuli. The test arena was a circular openfield arena $(\varnothing 11 \mathrm{~cm}$, height $5 \mathrm{~cm}$ ) with white walls and grey floor. The circular shape avoided that crabs place themselves in corners and stop moving, which would prevent measuring locomotor behaviour. The test began when the crab was placed in the centre of the test arena $(\varnothing 4.5 \mathrm{~cm})$ and filmed for 5 min with a HDR-CX240E camcorder (Sony, Tokyo, Japan) installed at $40 \mathrm{~cm}$ above the test arena, placed in the middle of the circular LED lamp (Neewer ${ }^{\circledR}$ ). Video-recordings were analysed a posteriori with Ethovision $\mathrm{XT}^{\circledR}$ (Noldus, Wageningen, The Netherlands). Locomotor behaviour was assessed through different parameters: the total distance moved $(\mathrm{cm})$, the mean velocity $\left(\mathrm{cm} \cdot \mathrm{s}^{-1}\right)$, the time spent at the periphery of the arena $(\mathrm{s})$ and the total time spent moving (s). The different parameters of Ethovision $\mathrm{XT}^{\circledR}$ were set to: sample rate $=5 / \mathrm{s}$; smoothing $=3$; minimum distance moved $=0.15 \mathrm{~cm}$; maximum distance moved $=3 \mathrm{~cm}$; threshold $=0.75-1$; averaging interval $=3$ samples.

\subsection{Statistical analysis}

Data were analysed with R Studio (Version 1.1.453-RStudio ${ }^{\odot}$, Inc., Boston, USA, https://www.rproject.org/) and Statistics Calculators (https://www.socscistatistics.com/). Results are expressed as means \pm standard error of the means (SEM). Non-parametric permutation test was used, as the data did not meet normality and homoscedasticity. We performed a permutation test for paired samples, as the same crab was tested at each experimental time point, using the function ezPerm from "ez" package. Mixed within-and-between Ss designs were used (i.e., repeated factor: exposure time; independent factor: experimental groups) to analyse absolute and relative colour change, and locomotor behaviour (i.e., normalised velocity; distance moved; time spent in periphery; total time spent moving). The number of iterations was set to 1000 . If the null hypothesis was rejected ( $\mathrm{p} \leq 0.05$ ), post-hoc permutation test for paired samples from "RVAidememoire package" (function pairwise.perm.t.test) was performed to reveal any differences among experimental groups and among exposure times. For post-hoc tests, false discovery rate (fdr) was applied using the Benjamini-Hochberg procedure (Benjamini and Hochberg, 1995). The permutation tests were complemented with tests performed on an online 
calculator astatsa.com (CC 2016 Navendu Vasavada): a Friedman test to analyse absolute colour change and to test for effects of exposure time within treatment groups, followed by sign test as post-hoc analysis as well as Kruskal-Wallis one-way non-parametric ANOVA to test differences among treatments at each time point, followed by Dunn's test as post-hoc analysis.

Sample sizes for juvenile crabs tested for colour change were as follows: (i) from white to black environment: control, $\mathrm{n}=16$; FLX5, $\mathrm{n}=15$; FLXVEN5, $\mathrm{n}=16$; (ii) from black to white environment: control, $\mathrm{n}=12$; FLX5, $\mathrm{n}=11$; FLXVEN5, $\mathrm{n}=11$. The varying number of crabs among the different groups and test conditions was due to the loss of individual crabs. Sample sizes for juvenile crabs that were tested for the locomotor behaviour were always 14 for each experimental group.

\section{Results}

\subsection{Colour change on opposite background}

\subsubsection{White to black environment}

\subsubsection{Absolute colour change}

Within the control group, crabs had a mean MGV of $108.4 \pm 35.1$ over the benchmark week, i.e., d-8, whereas during the experimental time course mean MGV progressively increased to a maximum of $127.4 \pm 37.3$ at d16 (Table. 1). Indeed, the MGV of the crabs after 21 hours adaptation to a white background turned out to differ significantly over the experimental time course (permutation test, $\mathrm{p}=0.004$ ). Post-hoc permutation test showed a difference of MGV between $\mathrm{d}-8$, i.e., the benchmark week, and each of the experimental time points $(\mathrm{d}-8-\mathrm{d} 2, \mathrm{p}=$ $0.02 ; \mathrm{d}-8-\mathrm{d} 9, \mathrm{~d}-8-\mathrm{d} 16$ and $\mathrm{d}-8-\mathrm{d} 23, \mathrm{p}=0.04$, respectively). Consequently, the control crabs were displaying a brighter carapace over time. Following 21 hours on white background, crabs from the control groups were able to get darker when placed on black background for 2 hours, but they were displaying a less dark carapace over time. After 2 hours on black background, crabs had a mean MGV of $90.0 \pm 26.8$ at d-8, whereas at d2, d9, d16 and d23 mean MGV increased progressively (Table. 1). As a matter of consequence, the MGV on black background after 2 hours changed significantly over the experimental time course (permutation test, $\mathrm{p}=$ 0.001). Post-hoc permutation test revealed a significant difference in the MGV between d- 8 and 
$\mathrm{d} 16$ as well as $\mathrm{d} 23(\mathrm{~d}-8-\mathrm{d} 16, \mathrm{p}=0.04 ; \mathrm{d}-8-\mathrm{d} 23, \mathrm{p}=0.05)$. In summary, the control group improved its capacity to display a high MGV, i.e., paler carapace, over time. On the other hand, the capacity to adapt to a darker background with a lower MGV, i.e., darker carapace, diminished throughout the entire experimental time course as a result of the general trend for the crabs to become brighter over the experimental period.

Concurrently, the FLX5 group showed the same pattern as the control with an average MGV of $105.5 \pm 30.4$ at $\mathrm{d}-8$, while it increased at $\mathrm{d} 2, \mathrm{~d} 9, \mathrm{~d} 16$ and $\mathrm{d} 23$ (Table. 1). The MGV on white background after 21 hours changed significantly over time (permutation test, $\mathrm{p}<0.001$ ). Posthoc permutation tests demonstrated a significant difference of MGV between d- 8 and each of the experimental time points, i.e., d2, d9, d16, d23, (d-8-d2, p = 0.01; d-8-d9, p = 0.007; d-8-d16, $p$ $=0.007 ; \mathrm{d}-8-\mathrm{d} 23, \mathrm{p}=0.007)$. As for control group, the crabs from the FLX5 group were becoming brighter over time. Furthermore, the MGV on black background after 2 hours was significantly different over the experimental time course (permutation test, $\mathrm{p}=0.002$ ). Post-hoc permutation test showed a significant difference of MGV between d-8 and d16, d23 (d-8-d16, p $=0.048 ; \mathrm{d}-8-\mathrm{d} 23, \mathrm{p}=0.04)$, but also between $\mathrm{d} 2$ and $\mathrm{d} 16, \mathrm{~d} 23(\mathrm{~d} 2-\mathrm{d} 16, \mathrm{p}=0.04 ; \mathrm{d} 2-\mathrm{d} 23, \mathrm{p}=$ 0.04). As for the control group, the increasingly paler carapace after 21 hours in a white environment reduced the capacity of the FLX5 group to adapt to a darker background.

Within FLXVEN5 group, crabs displayed a more stable MGV over time on either white or black environment (Table. 1); neither did the MGV on white background after 21 hours change significantly over time (permutation test, $\mathrm{p}=0.918$ ), nor did the MGV on black background after 2 hours (permutation test, $\mathrm{p}=0.419$ ). This means that the evolution of a brightening colouration observed over the experimental time course in the control and FLX5 groups did not occur in the FLXVEN5 group.

Overall, the control and FLX5 group showed a capacity to brighten after 21 hours on a white background, with an improved capacity to get paler, whereas FLXVEN5 group showed stable changes of colour over time (Table. 1).

Table 1. Mean Grey Values (MGVs) of juvenile crabs' carapace from the three experimental groups: control, fluoxetine at $5 \mathrm{ng} \cdot \mathrm{L}^{-1}(\mathrm{FLX})$ and combined with venlafaxine at $5 \mathrm{ng} \cdot \mathrm{L}^{-1}$ (FLXVEN) each after being placed in a white environment for 21 hours and subsequently transferred to a black environment for two hours. Benchmark week (d-8) and experimental time 
points $\mathrm{d} 2, \mathrm{~d} 9, \mathrm{~d} 16$ and $\mathrm{d} 23$. MGVs are expressed as means \pm SEM $(\mathrm{n}=15-16) ; *$ indicates a significant difference between the benchmark week and experimental time points; ** indicates a significant difference between $\mathrm{d} 2$ and other experimental time points (permutation test, pairwise post-hoc permutation test with fdr correction)

$21 \mathrm{~h}$ in white environment

\begin{tabular}{llllll}
\hline & $\mathrm{d}-8$ & $\mathrm{~d} 2$ & $\mathrm{~d} 9$ & $\mathrm{~d} 16$ & $\mathrm{~d} 23$ \\
\hline CONTROL & $108,4 \pm 35,1$ & $\mathbf{1 2 1 , 1} \pm \mathbf{3 7 , 1} *$ & $\mathbf{1 2 3 , 2} \pm \mathbf{3 8 , 8} *$ & $\mathbf{1 2 7 , 4} \pm \mathbf{3 7 , 3} *$ & $\mathbf{1 2 7 , 2} \pm \mathbf{3 7 , \mathbf { 1 }} *$ \\
\hline FLX & $105,5 \pm 30,4$ & $\mathbf{1 2 5 , 8} \pm \mathbf{3 2 , 3} *$ & $\mathbf{1 2 7 , 6} \pm \mathbf{3 5 , 2} *$ & $\mathbf{1 3 3 , 7} \pm \mathbf{2 5 , 9} *$ & $\mathbf{1 3 2 , 9} \pm \mathbf{2 9 , 0} *$ \\
\hline FLXVEN & $110,0 \pm 32,8$ & $122,0 \pm 29,8$ & $117,5 \pm 36,8$ & $109,7 \pm 31,9$ & $112,4 \pm 32,9$ \\
\hline
\end{tabular}

$2 \mathrm{~h}$ in black environment

\begin{tabular}{llllll}
\hline & $\mathrm{d}-8$ & $\mathrm{~d} 2$ & $\mathrm{~d} 9$ & $\mathrm{~d} 16$ & $\mathrm{~d} 23$ \\
\hline CONTROL & $90,0 \pm 26,8$ & $91,9 \pm 30,2$ & $93,6 \pm 23,4$ & $\mathbf{1 0 2 , 7} \pm \mathbf{2 4 , 6} *$ & $\mathbf{1 0 3 , 4} \pm \mathbf{2 3 , 7} *$ \\
\hline FLX & $89,5 \pm 23,5$ & $89,5 \pm 20,1$ & $98,2 \pm 25,1$ & $\mathbf{1 0 3 , 7} \pm \mathbf{2 0 , 7} * *$ & $\mathbf{1 0 2 , 6} \pm \mathbf{2 0 , 4} * *$ \\
\hline FLXVEN & $85,0 \pm 20,9$ & $102,0 \pm 20,1$ & $97,4 \pm 19,1$ & $94,0 \pm 17,5$ & $94,7 \pm 16,8$ \\
\hline
\end{tabular}

\subsubsection{Per cent colour change}

Untreated white adapted animals from both the benchmark week and the controls from $\mathrm{d} 2$ to $\mathrm{d} 23$ became about $18 \%$ darker when being placed for 2 hours in a black environment, but the individual variances were quite high $(18.5 \% \pm 9.51 \mathrm{SEM}$; fig.4). During the benchmark week, the capacity of colour change was similar for all treatment groups (Kruskal-Wallis, $\mathrm{p}=0.910$ ). In the FLX5 group, colour change varied significantly between the benchmark week and two of the experimental time points (Friedman, $\mathrm{p}=0.048$ ): the MGV increased by 14 percentage points to $27.8 \%$ on $\mathrm{d} 2$ and by 10 percentage points on $\mathrm{d} 23$ to $23.8 \%$ relative to the benchmark week, leading to significant differences between $\mathrm{d}-08, \mathrm{~d} 2$ and $\mathrm{d} 23$ (sign test, $\mathrm{p}=0.020$ for $\mathrm{d}-08-\mathrm{d} 23$ and d2-d23; table S1). A slight increase could also be observed for the control group, but without being statistically significant (Friedman, $p=0.338$ ). No increase, as compared to the benchmark week, was discernible for the FLXVEN5 group (Friedman, $\mathrm{p}=0.663$ ). The strong increase in colour change following FLX5-exposure and the largely unchanged coloration of the animals treated with FLXVEN5 lead to significant differences among the treatment groups (Kruskal Wallis, $\mathrm{p}=0.009$ ). Dunn's post hoc test revealed a significant difference in the capacity to 
change colour between the FLX5 and the FLXVEN5 group at the beginning of the exposure, i.e., $\mathrm{d} 2(14.1 \%$ vs. $27.8 \%$, respectively; $\mathrm{p}=0.013)$. The average colour change also differed among the treatment groups at the end of the experiment, i.e., d23, with 19.7\% \pm 0.86 SEM for the controls, $23.8 \% \pm 2.62$ SEM for the FLX5 animals and 15.4\% \pm 11.78 SEM for the FLXVEN5 group (Dunn's test, C-FLX5, p = 0.004 and FLX5-FLXVEN5, $\mathrm{p}=0.032$, respectively).

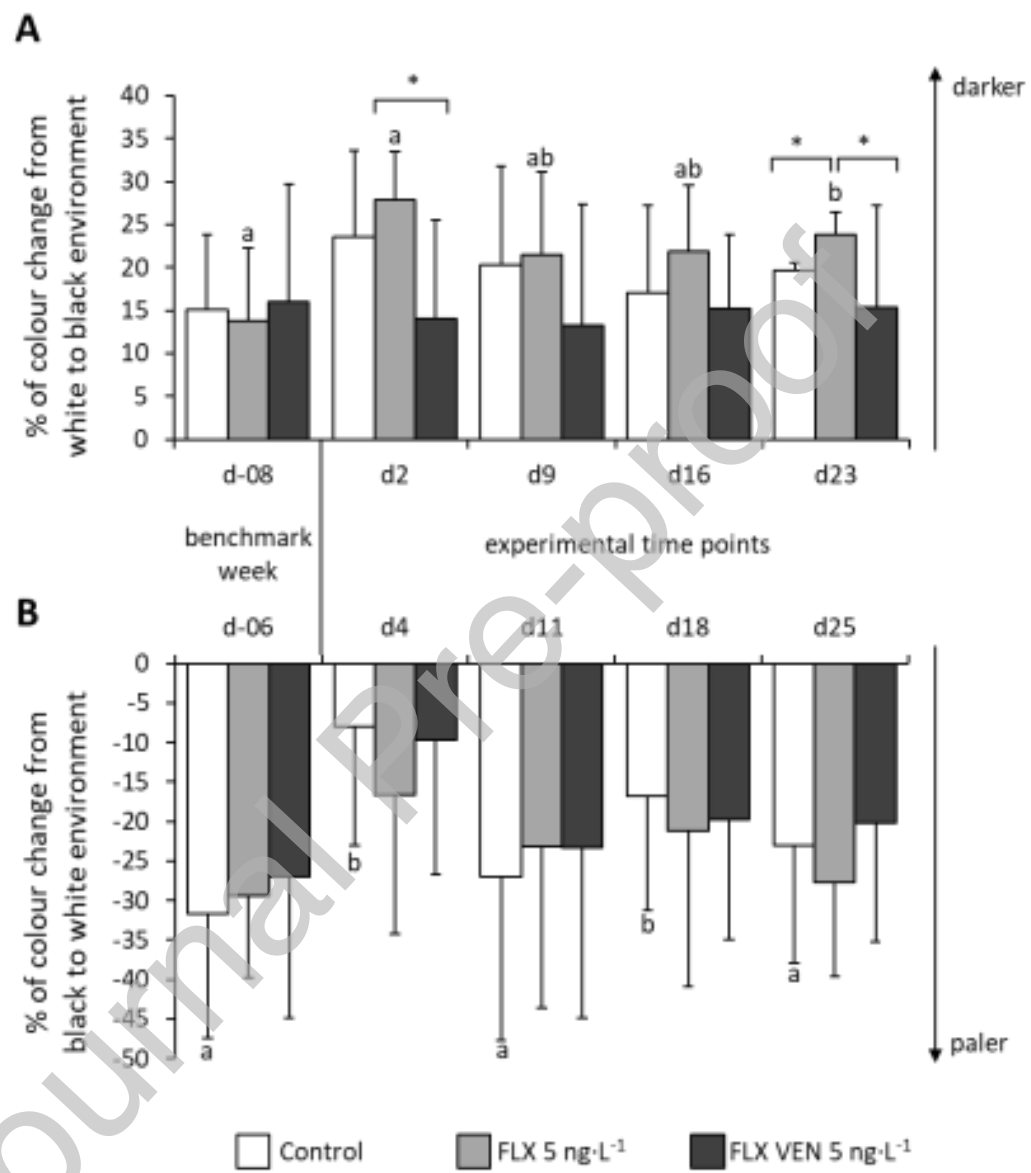

Figure 4. Per cent colour change of juvenile crabs, expressed as a percentage of absolute colour change, from the three experimental groups: control, fluoxetine at $5 \mathrm{ng} \cdot \mathrm{L}^{-1}$ (FLX) and FLX combined with venlafaxine at $5 \mathrm{ng} \cdot \mathrm{L}^{-1}$ (FLXVEN) each after being placed either (A) from white to black, and (B) from black to white environment. Means \pm SEM; $\mathrm{n}=11-16$; * indicate significant differences among experimental groups at $\mathrm{p} \leq 0.05$; the letters $\mathrm{a}$ and $\mathrm{b}$ indicate $\mathrm{a}$ difference among time points within the same group at $\mathrm{p} \leq 0.05$ (permutation test, pairwise posthoc permutation test with fdr correction)

\subsubsection{Normalised colour change}


Overall, the normalised colour change between white and black environment did not differ over the entire exposure time $(\mathrm{p}=0.785)$ (Fig 5.A). Albeit a constantly lower normalised colour change was observed for the FLXVEN5 group, in the majority of cases no significant difference among the treatments could be obtained, except for d16 (Kruskal Wallis, $\mathrm{C}_{\mathrm{d} 16}-\mathrm{FLX}_{\mathrm{d} 16^{-}}$ FLXVEN5 $\left.5_{\mathrm{d} 16}, \mathrm{p}=0.046\right)$. At this time point, the difference between the FLX5 and the FLXVEN5 group, which could be observed throughout the experiment, became statistically significant (Dunn's test, $\mathrm{p}=0.039$ ). The generally high variability in the data sets effectively prevented statistical significances for most of the obvious differences in the normalised colour change of animals exposed to FLX5 on the one hand, and FLXVEN5 on the other hand.
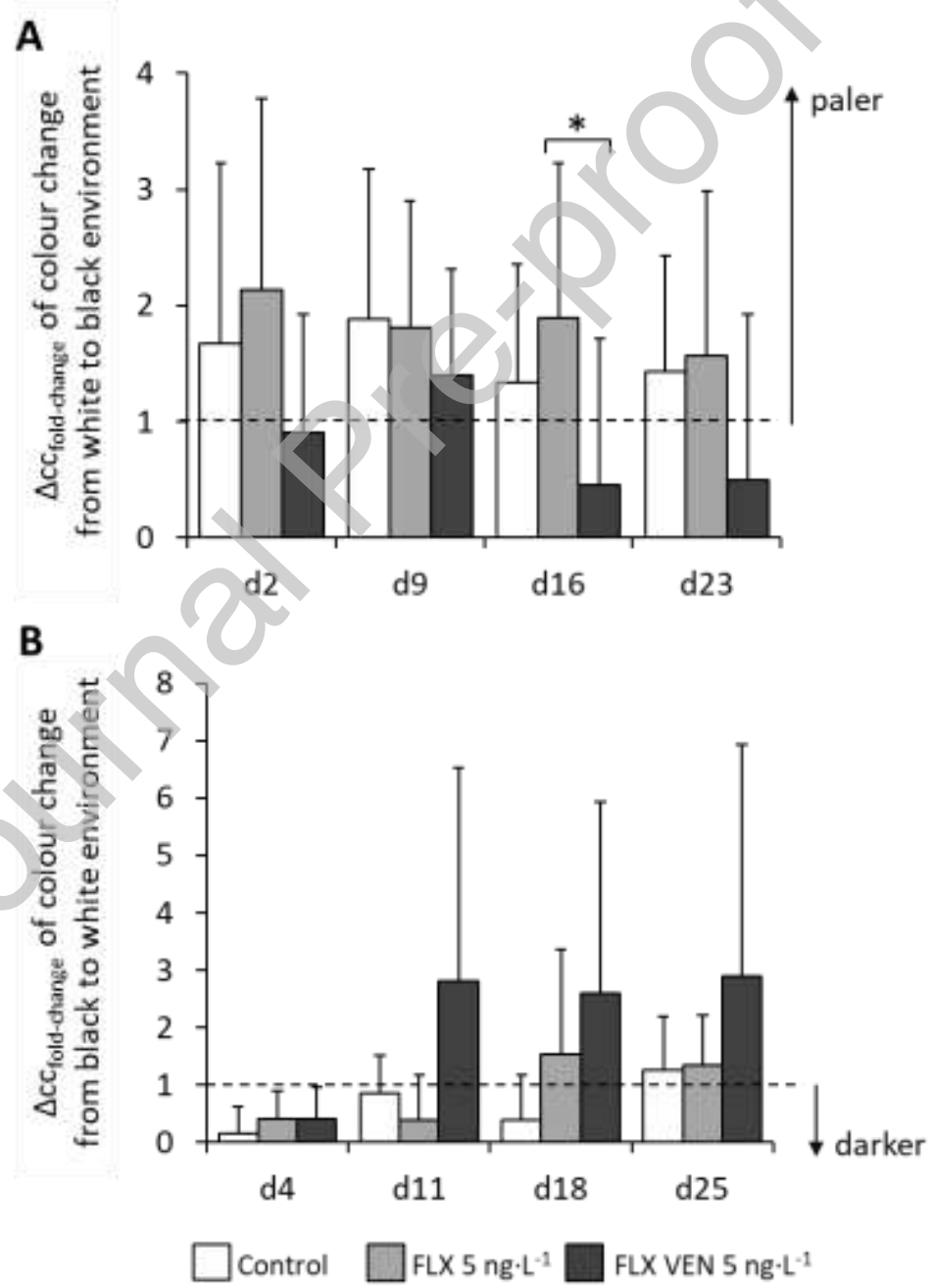

Figure 5. Relative colour change expressed as $\Delta \mathrm{cc}_{\text {fold-change }}$ between two opposite backgrounds by juvenile crabs exposed to fluoxetine alone at $5 \mathrm{ng} \cdot \mathrm{L}^{-1}$ (FLX) or in combination with 
venlafaxine at $5 \mathrm{ng} \cdot \mathrm{L}^{-1}$ each (FLXVEN), or in control condition; (A) from white to black, and (B) from black to white environment. Colour change test was done over four time points (day 2 and 4, day 9 and 11, day 16 and 18 as well as day 23 and 25). The dotted line represents the baseline corresponding to the averaged individual reference data to which colour change values were normalised with the values obtained for the benchmark week (for details see text). Means \pm SEM; $\mathrm{n}=11-16 ; *$, indicate a significant difference $(p<0.05)$ among treatment groups (permutation test, pairwise post-hoc permutation test with fdr correction)

\subsubsection{Black to white environment}

\subsubsection{Absolute colour change}

In the control group, the MGV after 21 hours in black environment was $85.3 \pm 21.5$ during the benchmark week, i.e., d-6, and kept increasing up to $102.1 \pm 23.0$ at $\mathrm{d} 25$ (Table. 2). Therefore, the MGV on a black background after 21 hours changed significantly over time $(\mathrm{p}=0.002)$. Post-hoc permutation tests showed a difference of MGV between d-6 and d18 as well as d25 (d6-d18, d-6-d25, p = 0.02, respectively), as well as between d11, d18 and d25 (d11-d18, d11$\mathrm{d} 25, \mathrm{p}=0.02$, respectively). A trend to become brighter may be noticed between $\mathrm{d} 4, \mathrm{~d} 18$ and $\mathrm{d} 25$ (d4-d18, $\mathrm{p}=0.056 ; \mathrm{d} 4-\mathrm{d} 25, \mathrm{p}=0.067$ ). Thus, crabs from the control group were exhibiting poorer colour change on black background, i.e., getting less dark over time. Correspondingly, the MGV on a white background after 2 hours changed significantly over time $(\mathrm{p}=0.002)$. Post-hoc permutation tests only highlighted a trend between d-6 and d18 as well d26 (d-6-d18, p = 0.08; $\mathrm{d}-6-\mathrm{d} 25, \mathrm{p}=0.07)$. Because the crabs adapted to a black background over 21 hours became brighter over time, alike the crabs that were adapted to a white background after 21 hours, the crabs from control group were able to improve their MGV when placed for 2 hours on a white background, i.e., they were getting brighter during the experiment. Generally, the values corresponded to those that were observed when crabs were kept for 21 hours on a white background (Table. 2).

Although the groupwise permutation test indicated a significant change of the MGV in the FLX5 group after 21 hours over time (permutation test, $\mathrm{p}=0.002$ ), the post-hoc permutation tests did not demonstrate any significant difference among the experimental time points. Similarly, the MGV on white background after 2 hours was significantly different over time (permutation test, 
$\mathrm{p}<0.001)$ across all experimental time points, but the post-hoc permutation test failed to reveal which of the time points were significantly different.

For the FLXVEN5 group, the MGV on black background after 21 hours was not significantly different (permutation test, $\mathrm{p}=0.057$ ), even if a trend towards an increased MGV over time may be noticed. The MGV on white background after 2 hours was significantly different (permutation test, $\mathrm{p}=0.008$ ), but the post-hoc permutation test failed to highlight any significant difference among time points.

Overall, crabs from the control group expressed a higher MGV over time, i.e., displaying a paler carapace, even when placed on black background. By trend this was the case in the exposed crabs as well. For all groups, the MGV at d4 was comparatively low, which is likely to be responsible for the significant differences over time.

Table 2. Mean Grey Values (MGV) of juvenile crabs carapace from the three experimental groups: control, fluoxetine at $5 \mathrm{ng} \cdot \mathrm{L}^{-1}(\mathrm{FLX})$ and combined with venlafaxine at $5 \mathrm{ng} \cdot \mathrm{L}^{-1}$ (FLXVEN) after being placed in a black environment for 21 hours and then transferred to a white environment for 2 hours. Benchmark week, i.e., $\mathrm{d}-6$, and the experimental time points, i.e., $\mathrm{d} 4, \mathrm{~d} 11, \mathrm{~d} 18$ and $\mathrm{d} 25 . \mathrm{MGV}$ are expressed as mean \pm SEM $(\mathrm{n}=11-12) .{ }^{*}$ indicates a significant difference between the benchmark week and experimental time points; ** indicates a significant difference between $\mathrm{d} 11$ and other experimental time points (permutation test, pairwise post-hoc permutation test with fdr correction)

$21 \mathrm{~h}$ in black environment

\begin{tabular}{llllll} 
& $\mathrm{d}-6$ & $\mathrm{~d} 4$ & $\mathrm{~d} 11$ & $\mathrm{~d} 18$ & $\mathrm{~d} 25$ \\
\hline CONTROL & $85,3 \pm 21,5$ & $72,9 \pm 45,0$ & $\mathbf{9 1 , 5} \pm \mathbf{2 1 , 6} *$ & $\mathbf{1 0 5 , 4} \pm \mathbf{2 0 , 5} * / * *$ & $\mathbf{1 0 2 , 1} \pm \mathbf{2 3 , 0} * / * *$ \\
\hline FLX & $94,7 \pm 23,1$ & $68,5 \pm 42,2$ & $101,3 \pm 25,5$ & $106,7 \pm 18,6$ & $99,9 \pm 18,6$ \\
\hline FLXVEN & $82,5 \pm 22,7$ & $78,4 \pm 41,5$ & $92,0 \pm 21,9$ & $99,6 \pm 23,0$ & $95,3 \pm 20,8$ \\
\hline
\end{tabular}

$2 h$ in white environment

\begin{tabular}{llllll} 
& $\mathrm{d}-6$ & $\mathrm{~d} 4$ & $\mathrm{~d} 11$ & $\mathrm{~d} 18$ & $\mathrm{~d} 25$ \\
\hline CONTROL & $113,3 \pm 33,1$ & $82,4 \pm 57,5$ & $117,0 \pm 37,4$ & $\mathbf{1 2 5 , 2} \pm \mathbf{3 6 , 6} *$ & $\mathbf{1 2 7 , 0} \pm \mathbf{3 8 , 0} *$ \\
\hline FLX & $122,8 \pm 33,9$ & $85,0 \pm 58,6$ & $122,8 \pm 30,5$ & $128,8 \pm 30,7$ & $127,8 \pm 28,8$ \\
\hline FLXVEN & $106,0 \pm 36,8$ & $86,7 \pm 51,9$ & $114,1 \pm 40,0$ & $119,9 \pm 36,6$ & $115,6 \pm 34,7$ \\
\hline
\end{tabular}




\subsubsection{Percent colour change}

On average, all black adapted animals became about $18 \%$ brighter when being placed for 2 hours in a white environment $(18.5 \% \pm 3.16 \mathrm{SEM}$; fig.4 $)$. Some instability in the capacity of colour change from black to white could be noted in all treatment groups: there was a notable depression in their ability of becoming brighter at $\mathrm{d} 4$ as well as a slightly reduced amplitude at d18. However, these fluctuations over time were statistically significant in the control group only (Friedman, $\mathrm{p}=0.003$; sign test, $\mathrm{d}-06-\mathrm{d} 4$ and d-06-d18, $\mathrm{p}=0.004$, respectively). No significant effects of the antidepressant treatments on the capacity of becoming brighter when adapted to a black background could be detected for any of the time points.

\subsubsection{Normalised colour change}

The experimental time course had a significant effect on colour change between white and black environment (permutation test, $\mathrm{p}=0.001$ ), but without any effect of treatment (permutation test, $\mathrm{p}=0.984$ ) (Fig 5. B). Pairwise post-hoc permutation test highlighted a difference between $\mathrm{d} 4$ and $\mathrm{d} 11, \mathrm{~d} 18, \mathrm{~d} 25$ (d4-d11, $\mathrm{p}=0.006$; d4-d18, $\mathrm{p}=0.036$; $\mathrm{d} 4-\mathrm{d} 25, \mathrm{p}=$ 0.006). Hence, the crabs of all experimental groups were continuously getting paler over time relative to the benchmark week. The antidepressant treatment, notably in the FLXVEN5 group, may have advanced this process slightly, but the variability in colour change was much too high to obtain any statistical significance in the differences among the groups.

\subsection{Locomotor behaviour}

\subsubsection{Distance moved}

During the benchmark week, crabs moved on average a distance of $425.9 \pm 134.3 \mathrm{~cm}$ during the 5 min test $(n=42)$. Following exposure, the distance moved was significantly different among groups (permutation test, $\mathrm{p}=0.009$ ). Pairwise post-hoc permutation test highlighted differences between FLXVEN5 and the control and FLX5 groups (FLXVEN5-control, p = 0.012; FLXVEN5-FLX5, p = 0.006) (Fig. 6.A). Crabs from FLXVEN5 group walked a longer distance than controls or FLX5 group at all experimental time points. Furthermore, the distance moved was significantly different over time (permutation test, $\mathrm{p}=0.037$ ). Notwithstanding, pairwise post-hoc permutation test did not show a significant difference over time, but a trend between $\mathrm{d} 3$ and $\mathrm{d} 17(\mathrm{p}=0.072)$. This result is likely to be associated with an increasing intra-group 
variability in the FLXVEN5 group at $\mathrm{d} 17$ and $\mathrm{d} 24(\mathrm{~d} 3=1.56 \pm 1.22, \mathrm{~d} 10=1.76 \pm 0.78, \mathrm{~d} 17=$ $2.25 \pm 1.59, \mathrm{~d} 24=2.49 \pm 2.69)$. Nevertheless, one may notice that crabs from FLXVEN5 on average increased the distance moved over time, while control and FLX5 group exhibited a more consistent variability during the entire exposure time.

A

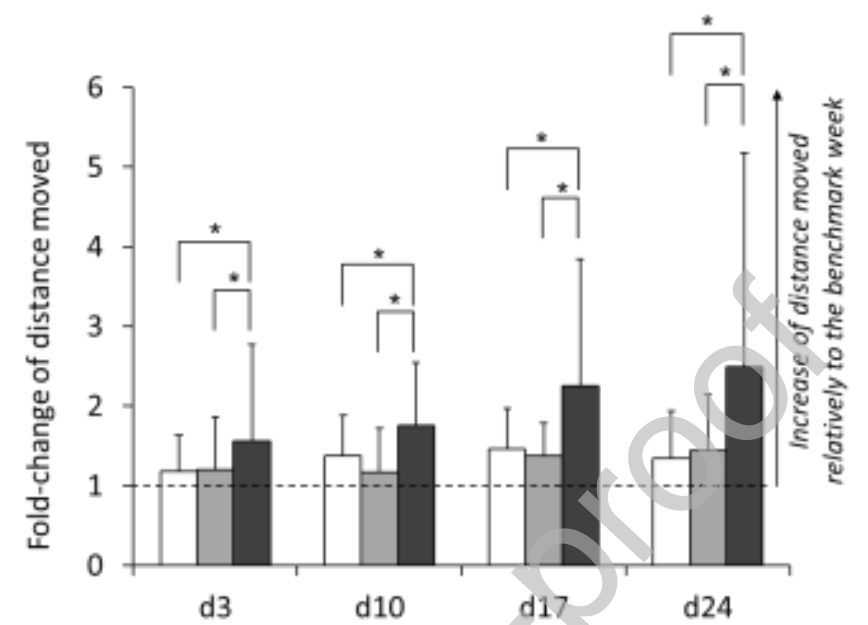

B

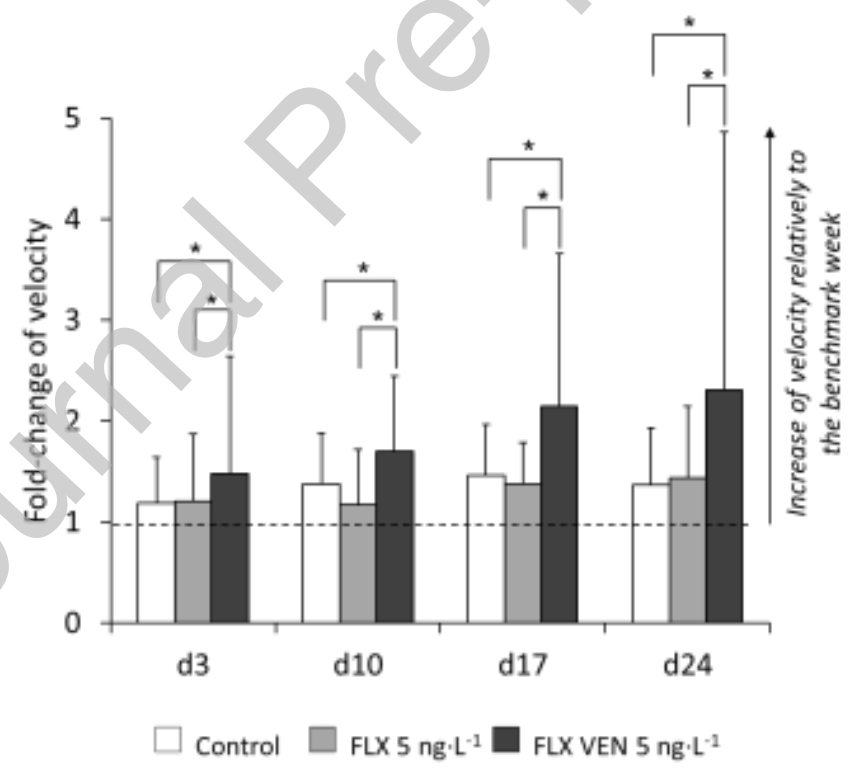

Figure 6. Distance moved (A) and velocity (B), expressed as fold-change, of juvenile crabs during a $5 \mathrm{~min}$ openfield test at four time points (d=day) of exposure to fluoxetine alone at 5 $\mathrm{ng} \cdot \mathrm{L}^{-1}$ (FLX), in combination with venlafaxine at $5 \mathrm{ng} \cdot \mathrm{L}^{-1}$ each (FLXVEN), or in control condition. Values are averaged individual data normalised with values obtained from the benchmark week (for details see text). The dotted line represents the baseline corresponding to 
the benchmark week. Means $\pm \mathrm{SEM} ; \mathrm{n}=14 ; *$, significantly different among experimental groups at $\mathrm{p} \leq 0.05$

\subsubsection{Velocity}

The average velocity of crabs during the benchmark week was $1.42 \pm 0.45 \mathrm{~cm} \cdot \mathrm{s}^{-1}(\mathrm{n}=42)$. The velocity differed significantly among experimental groups (permutation test, $\mathrm{p}=0.008$ ). Pairwise post-hoc permutation test demonstrated that FLXVEN5 group had a greater velocity than the control and the FLX5 group (FLXVEN5-control, $p=0.006$; FLXVEN5-control, $p=0.006$ ) (Fig. 6.B). Crabs exposed to FLXVEN5 walked on average at a greater velocity than control or FLX5 groups. In addition, velocity was significantly different over time $(\mathrm{p}=0.030)$. However, pairwise post-hoc permutation test did not show any significant difference among time points, but revealed trends between $\mathrm{d} 3$ and $\mathrm{d} 17, \mathrm{~d} 24(\mathrm{~d} 3-\mathrm{d} 17, \mathrm{p}=0.072 ; \mathrm{d} 3-\mathrm{d} 24, \mathrm{p}=0.096)$. As for the distance moved (see above), this trend, i.e., absence of significant increase over time, is owed to variability in the data, which lowered statistical power. It may be noticed that control and FLX5 groups kept roughly a consistent variability throughout the entire experimental time course.

\subsubsection{Time spent in the periphery}

During the benchmark week, crabs spent the majority of their time in the periphery of the openfield arena: $296.3 \pm 11.5$ s. Following exposure, the time spent in the periphery remained stable among groups (permutation test, $\mathrm{p}=0.378$ ) and for any of the time points during the experimental time course (permutation test, $\mathrm{p}=0.764$ ). Crabs from all groups spent the vast majority of their time in the periphery of the openfield arena.

\subsubsection{Total time spent moving}

During the benchmark week, juvenile crabs spent on average $162.9 \pm 43.3 \mathrm{~s}$ moving in the openfield arena. The total time spent moving was significantly different among groups (permutation test, $\mathrm{p}=0.036$ ). Pairwise post-hoc permutation test showed that FLXVEN5 group spent more time moving than controls and FLX5 group (FLXVEN5-control, $p=0.015$; FLXVEN5-FLX5, $\mathrm{p}=0.015$ ) (Fig. 7). This is in line with results from the parameters distance moved and velocity. A trend to increase the total time spent moving emerged over time (permutation test, $\mathrm{p}=0.072$ ), which followed the same pattern as observed for velocity and 
distance moved. Moreover, a higher intragroup variability was observed in FLXVEN5 group, whereas in control and FLX5 group it remained stable.

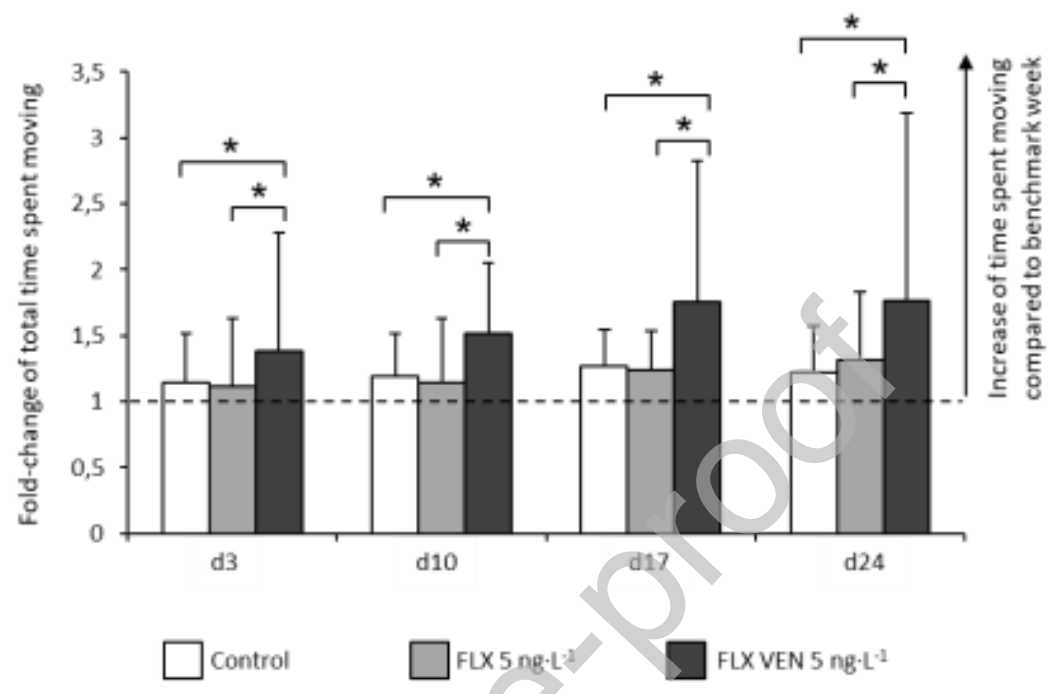

Figure 7. Time spent moving by juvenile crabs during a 5 min openfield test expressed as foldchange over four time points (d=days) of exposure to fluoxetine alone at $5 \mathrm{ng} \cdot \mathrm{L}^{-1}$ (FLX) or in combination with venlafaxine at $5 \mathrm{ng} \cdot \mathrm{L}^{-1}$ each (FLXVEN), or in control condition. Dotted line is representing the baseline of reference data. Values are normalised and expressed as means and SEM. *, indicates a significant difference among experimental groups $\mathrm{p} \leq 0.05$ (permutation test, pairwise post-hoc permutation test with fdr correction).

In summary, the data suggest effects of antidepressants on colour change. The extreme variability as well as occasionally opposing responses rendered it difficult to obtain statistically significant differences for many of the differences comprised in the data. Nevertheless, the pattern of colour changes, i.e., brightening of the carapace over time, expressed by the control and FLX groups were not observed in FLXVEN5 group.

By contrast, the antidepressant treatment clearly and significantly affected locomotor behaviour. The FLXVEN5-exposure resulted in a significantly higher velocity, a greater distance moved and more time spent moving as compared to the non-exposed controls or the FLX5-treatment throughout the entire experimental period, i.e., from $\mathrm{d} 3$ to $\mathrm{d} 24$. 
Whether this is due to the VEN in the mixture or the cumulated concentration of $10 \mathrm{ng} \cdot \mathrm{L}^{-1}$ with the two antidepressants cannot be told without testing either of the antidepressants alone and in mixtures at different concentrations.

\section{Discussion}

\subsection{Colour change on opposite background}

When juvenile shore crabs where placed from the opposite background into an either black or white environment, they were able to adapt their luminance, either becoming darker or whiter over two hours, as previously demonstrated by Stevens et al. (2014a). When white adapted animals were placed on a black background, they became about $20 \%$ darker on average, a value consistent with the magnitude of colour change observed in the transparent Crangon crangon (Ford and Feuerhelm, 2020; Siegenthaler et al., 2018). The amplitude of colour change was, however, extremely variable ranging from half to double of the average colour change. This high inter-individual variability in the capacity of becoming darker or brighter may be explained in part by the highly polymorphic morphological colouration of the cuticle, which overlays the physiological colour change of the chromatophores situated in the epidermis. High variability in colour change has been repeatedly reported for various crustacean species, including species with transparent cuticles. It is likely to relate $(i)$ to the complexity of the response (Rao, 2001) and (ii) derives from the many external and internal factors that are influencing it, amongst them stress (Detto et al., 2008; Hanumante and Fingerman, 1982a, 1981; Siegenthaler et al., 2018). Moreover, the impression that animals were becoming paler over time could derive from the artificial lighting to which they continuously adapted (Siegenthaler et al., 2018). Many crustaceans become darker during the day, protecting them with melanin against UV radiation (Fuhrmann et al., 2011). In the experimental environment, UV light was, however, not a factor that would have triggered darkening.

Animals exposed to antidepressants seemed to be affected in their capacity to respond to darker, but not to lighter coloured backgrounds. Dark-adaptation appeared to stabilise towards the end of the experiment at around $20 \%$ in the control animals $(19.71 \% \pm 0.86$ SEM), while the group treated with FLX at $5 \mathrm{ng} \cdot \mathrm{L}^{-1}$ seemed to stimulate colour change transiently, indicated by a significant darkening of $27 \%$ at $\mathrm{d} 2(27.80 \% \pm 5.70 \mathrm{SEM})$ and a significantly higher normalised 
colour change at d16 compared to the FLXVEN5 treatment. The latter group, i.e., FLX plus VEN at $5 \mathrm{ng} \cdot \mathrm{L}^{-1}$ each, clearly demonstrated attenuated colour change. Firstly, the animals did not become as pale as those of the two other treatments when adapted to a white background for 21 hours. Secondly, they did not darken as much as the controls and, notably, the FLX treated animals (Table. 1). Accordingly, the mean colour change in the FLXVEN5 group was only about $15 \%$ at all time points $(14.78 \pm 11.94)$ and the normalised colour change was mostly lower than that of the benchmark week, i.e., less than a onefold colour change. Both, the stimulation in the FLX5 and the attenuation in the FLXVEN5 group led to significant differences between the two treatments.

In a series of experiments Fingerman et al., (1981) as well as Hanumante and Fingerman, (1983, 1981) investigated the role of the monoamine neurotransmitters 5-HT, DA and NE on the antagonistic action of red-pigment dispersion and aggregation as well as on melanin dispersion, with the respective neuropeptide hormones being involved in the colour change of Uca pugilator and Macrobrachium ohione (reviewed in Hanumante and Fingerman, 1982a). In their studies they also used 5-HT potentiators, such as FLX (Hanumante and Fingerman, 1983). They found that FLX accelerated the dispersion of pigments in the erythrophores when crabs were transferred from a white to a black background and that it potentiated the indirect action of 5-HT as a neurotransmitter of colour change in $U$. pugilator and M. ohione. On the contrary, FLX slowed down the concentration of the pigments when crabs were transferred from a black to a white background. The latter could, however, not be confirmed in the present study. Hanumante and Fingerman (1982b) further demonstrated that drugs supposed to reduce norepinephrine levels reduced the dispersion and increased the aggregation of melanin. By using different pharmaceuticals that act on monoamine signalling, these authors could demonstrate that monoamines act indirectly on colour change via the nervous system, thus triggering the release of pigment dispersing and concentrating neuropeptide hormones, i.e., PDH and RPCH. Our data suggest that this was also the case in $C$. maenas treated with $5 \mathrm{ng} \cdot \mathrm{L}^{-1}$ waterborne FLX in the present study, as the maximum colour change for all treatments and time points was observed for FLX5 at d2, both as \% colour change (27\%) and an approximately twofold change relative to the benchmark value. Moreover, the FLX5 group displayed the highest amplitudes of colour change throughout the entire exposure period, being on average $8 \%$ above their respective reference value (data not shown). 
Other monoamines also intervene in the control of chromatophores and colour change. For instance, DA promotes pigment concentration via $\mathrm{RPCH}$ in the erythrophores (Hanumante and Fingerman, 1983) and NE — or rather octopamine - elicits pigment dispersion in melanophores. These may have interfered with the response to a white environment after dark-adaptation, but may have also affected the adaptation to a white environment before being transferred to a black background. In addition, other neuropeptides, such as the crustacean cardioactive peptide (Nery et al., 1999) or corazonin (Porras et al., 2003), may act on pigment dispersion and aggregation within the chromatophores. How monoamines regulate these neuropeptides in crustaceans, such as C. maenas, remains to be elucidated. Nery et al. (1999) discovered that crustacean cardioactive peptide acted as a full agonist on pigment dispersion in the erythrophores of the freshwater shrimp Macrobrachium potiuna. In the crayfish Procambarus clarki, Porras et al. (2003) demonstrated an antagonistic action of corazonin on erythrophores and leucophores, with corazonin promoting pigment dispersion in leucophores together with a concurrent aggregation of pigments in the erythrophores (Dircksen, 2013). In line with these findings, Alexander et al. (2018) did not observe any activity of corazonin on pigment dispersion in C. maenas adapted to a white background, i.e., with maximal aggregation of red pigment, but it might have maintained the leucophore pigment granules fully dispersed, which was not investigated by these authors.

It should be further noted that the above mentioned studies used a semi-quantitative chromatophore assay and required high drug levels, i.e., a dose of $20 \mu \mathrm{g}$ FLX, that was directly injected into the animals in order to obtain significant results. The present study, however, used low environmental levels of antidepressants, which in combination may provoke the concurrent release of different chromatophorotropins. Theoretically, FLX alone should have stimulated the colour change when placing crabs from a white background, on which red pigment and melanin should be fully aggregated, to a black background, which favours the dispersion of the dark pigments. Indeed, the relatively strong colour change in the FLX5 treated animals, notably at $\mathrm{d} 2$, conforms to this expectation. The combination of the two antidepressants FLX and VEN, however, obviously produced the opposite effect. The results rather indicate a significant decrease in the amount of darkening of white-adapted crabs treated with FLXVEN5 when being transferred to a black environment. Actually, this treatment group displayed the lowest overall MGVs when adapted to either black or white environments (Table. 1 and table. 2). As a matter of consequence, the capacity to change colour, either as $\triangle \mathrm{CC}$, or $\%$ of the absolute MGVs, when 
transferred from a white to a black environment - to which they perfectly adapted — was reduced, simply because these animals did, on average, not become as pale as the controls or the FLX5 group. Assuming a persistent effect of VEN on NE/octopamine and thus on pigment dispersion in the melanophores, this may have overruled the more dynamic changes due to FLX exposure and attenuated white adaptation. Further studies investigating the effects of VEN alone are needed to confirm its putative effect on pigment dispersion.

\subsection{Locomotor behaviour}

Juvenile shore crabs exhibited a stimulation of their locomotor behaviour in presence of FLX plus VEN at $5 \mathrm{ng} \cdot \mathrm{L}^{-1}$ each, whereas no effect of FLX alone was observed. Distance moved, velocity and total time spent moving increased significantly at all time points of exposure, beginning already at day 3 . This shows that a short exposure to very low concentrations of only two antidepressants can have a significant impact on behaviour. Moreover, the increase of locomotion tended to rise over the 24 days of exposure, which may be indicative of an accumulation of the antidepressants (Robert et al., 2017). Results of previous research on locomotor-related behaviours are inconsistent and vary greatly depending on the employed concentration as well as depending on the study organism; an overview is provided in Table 3.

Table 3. Summary of results of different studies on locomotor behaviour in aquatic species exposed to the antidepressant fluoxetine (FLX) or venlafaxine (VEN).

\begin{tabular}{|c|c|c|}
\hline Species & $\begin{array}{l}\text { Conditions of exposition: duration, } \\
\text { contaminant, concentration }\end{array}$ & Locomotor behaviour \\
\hline Mesquita et al., 2011 Carcinus maenas & $\begin{array}{c}7 \text { days } \\
{[\mathrm{FLX}]=120-750 \mu \mathrm{g} \cdot \mathrm{L}^{-1}}\end{array}$ & $\begin{array}{l}\boldsymbol{\pi} \text { distance moved } \\
\boldsymbol{\pi} \text { time spent moving } \\
\text { no effect on velocity }\end{array}$ \\
\hline Hemigrapsus japonica & $\begin{array}{c}\text { 7-9 weeks } \\
{[\mathrm{FLX}]=30 \mathrm{ng} \cdot \mathrm{L}^{-1}}\end{array}$ & $\boldsymbol{\lambda}$ active behaviour \\
\hline $\begin{array}{ll}\text { Bossus et al., 2014; } & \text { Echinogammarus marinus } \\
\text { De Castro-Català et } & \text { and Gammarus pulex } \\
\text { al., } 2017 & \end{array}$ & $\begin{array}{c}\text { 1-14 days } \\
{[\mathrm{FLX}]=1-100 \mathrm{ng} \cdot \mathrm{L}^{-1}}\end{array}$ & $\pi$ velocity \\
\hline $\begin{array}{l}\text { Urosalpinx cinerea and } \\
\text { Lithopoma americanum }\end{array}$ & $\begin{array}{c}\text { Few hours } \\
{[\text { VEN }]=31.3 \mu \mathrm{g} \cdot \mathrm{L}^{-1}} \\
{[\text { FLX }]=345 \mu \mathrm{g} \cdot \mathrm{L}^{-1}}\end{array}$ & $\begin{array}{l}\boldsymbol{\lambda} \text { distance travelled } \\
\boldsymbol{y} \text { distance travelled }\end{array}$ \\
\hline Hamilton et al., 2016 Pachygrapsus crassipes & $15 \mathrm{~min}$ & no effect on time spent \\
\hline
\end{tabular}




\begin{tabular}{llcc}
\hline & & {$[\mathrm{FLX}]=5-25 \mathrm{mg} \cdot \mathrm{L}^{-1}$} & moving \\
\hline Kubec et al., 2019 & Procambarus virginalis & {$[\mathrm{VEN}]=1 \mu \mathrm{g} \cdot \mathrm{L}^{-1}$} & $\begin{array}{c}\text { no alteration of locomotor } \\
\text { behaviour }\end{array}$ \\
\hline Tierney et al., 2016 & Orconectes rusticus & $10 \mathrm{days}$ & $\searrow$ locomotor activity \\
\hline De Lange et al., 2006 & Gammarus pulex & {$[\mathrm{FLX}]=2-500 \mathrm{ng} \cdot \mathrm{L}^{-1}$} & \\
\hline Barry, 2018 & Sclerophrys arabica & $35 \mathrm{~min}$ & $\searrow$ swimming activity \\
\hline Barry, 2013 & Aphanius dispar & {$[\mathrm{FLX}]=10-100 \mathrm{ng} \cdot \mathrm{L}^{-1}$} & \\
\hline
\end{tabular}

オ: increase, $\searrow$ : decrease

In summary, numerous studies investigated locomotor behaviour after an exposure to either FLX or VEN with very different outcomes in relatively similar experimental settings. Concerning thigmotaxis, no effect, neither with FLX alone, nor in combination with VEN at $5 \mathrm{ng} \cdot \mathrm{L}^{-1}$ was observed in juvenile shore crabs. Two studies corroborate these results: Mesquita et al. (2011) did not observe any significant effect of FLX on thigmotaxis in C. maenas. Thompson et al. (2017) showed that after injection of VEN into zebrafish embryos, the larvae did not behave any different from the controls. Hence, thigmotaxis does not seem to be affected by the presence of FLX or VEN at environmentally realistic concentrations.

The altered locomotor behaviour observed in juvenile shore crabs is likely to be linked to the modification of the endogenous concentrations of monoamines such as 5-HT or DA, known to have a role in locomotion of various species. McPhee and Wilkens (1989) showed that injection of 5-HT increased locomotor behaviour in C. maenas, whereas DA had no effect. Along the same lines, in the terrestrial snail Helix lucorum, injection of 5-HT stimulated locomotion and accelerated crawling, while DA decreased locomotion and even prevented it in some animals (Pavlova, 2001). On the contrary, in juvenile lobsters Homarus americanus, injection of high doses of 5-HT reduced locomotion by lowering coordination (Peeke et al., 2000). In the crayfish Procambarus clarkii, injection of low doses of 5-HT reduced locomotion as well (Tierney and Mangiamele, 2001). As with colour change and crypsis, the complexity of locomotor responses (Jordan et al., 2007), their hormonal regulation-for instance by crustacean hyperglycaemic hormone $(\mathrm{CHH})$ - as well as their modulation by the various monoamines appears to result in a highly complex and variable locomotor behaviour. Furthermore, it is unclear to which extent the monoamines act directly on basic motor patterns (Harris-Warrick, 2011), and to which extent they promote the release of neuropeptide hormones, such as $\mathrm{CHH}$, which may relate to increased 
locomotor activity (Aquiloni et al., 2012; Morris et al., 2010). With respect to the latter, the action of neurohormones from the eyestalk is not straightforward. In an environmental setting, these neurohormones seem to regulate persistent circadian and tidal rhythms of locomotor activity, which increases with darkness and high tide (Strauss and Dircksen, 2010; Williams and Naylor, 1969). Eyestalk extracts, which contain a crude mixture of neuropetides from the sinus gland appeared to depress locomotor activity, whereas eyestalk ablation increased arrhythmic locomotor activity (Williams et al., 1979). On the other hand, CHH is correlated with increased exercise (Morris et al., 2010) and when injected into the crayfish, Procambarus clarkii, the animals spent less time motionless (Aquiloni et al., 2012). It is likely that antidepressants, such as FLX, increase the release of CHH (Robert et al., 2016) and that this may equally contribute to an increased locomotor activity. The complexity of interacting neuromodulators and neurohormones might even be increased when exogenous substances interfere with the finetuned regulation of the animal's physiological state and locomotion. In the present study, however, the combination of two antidepressants at environmentally realistic concentrations resulted in a rather clear-cut increase of locomotor activity. Further studies are needed to answer the question whether this was due to the elevated concentration of $10 \mathrm{ng} \cdot \mathrm{L}^{-1}$ of antidepressants in total, or due to the presence of $5 \mathrm{ng} \cdot \mathrm{L}^{-1} \mathrm{VEN}$ in the combination.

\section{Conclusions}

Albeit antidepressants may be detected and quantified in marine environments at concentrations way below levels of toxicity, they may still have pernicious effects on sensitive physiological parameters and associated behaviour in non-target organisms. Juvenile crabs exposed to environmentally realistic concentrations of cumulated antidepressants clearly exhibited a different pattern of colour change than controls over the experimental time course, showing signs of a reduced capacity to adapt to their respective microhabitats. Furthermore, a significant increase in locomotor activity was demonstrated in presence of the two antidepressants. These results highlight the potentially sub-lethal effects of very low concentrations of antidepressants in the aquatic environments. Juvenile crabs may become more vulnerable to predators if less well camouflaged or more visible by moving too quickly. Yet, the high variability of these behavioural responses, notably of colour change, makes it difficult to assess negative consequences for survival in crustaceans of the apparently heterogeneous intertidal. It will, 
therefore, be necessary to scrutinise the sources causing this variability and to identify the mechanisms responsible for the variation in crypsis and/or locomotion.

The combination of antidepressants showed more pronounced effects on colour change and locomotor behaviour than FLX alone. This confirms that the notoriously low concentrations of single antidepressants in the water bodies are not an argument in favour of their innocuousness, but that rather the cumulated concentrations of several antidepressants and some of their active metabolites need to be considered for estimating the risk emanating from this class of emerging micropollutants. Further studies are needed to determine the contribution of each single antidepressant and their interaction in mixtures of antidepressants using less complex behavioural analyses that allow for high-throughput.

\section{Declaration of interests}

The authors declare that they have no known competing financial interests or personal relationships that could have appeared to influence the work reported in this paper.

\section{Acknowledgements}

This research work was supported by a doctoral grant from Normandy Region provided by the Research Federation CNRS 3730 SCALE (SCiences Appliquées à L'Environnement).

The authors wish to thank the technical staff of UMR I-02 SEBIO, Mayélé Burlion-Giorgi for her help in collecting and caring the animals and Stéphanie Olivier for her help during behavioural experiments. The authors gratefully acknowledge Christelle Jozet-Alves and Romain Coulaud for their help with R, statistical analyses and graphic editing.

\section{Authors' contribution}

A.C, C.B, T.K developed and designed the experiment and data analyses; A.C performed the experiment and data analyses; A.C, C.B, T.K wrote and approved the manuscript. 


\section{References}

Alexander, J.L., Oliphant, A., Wilcockson, D.C., Audsley, N., Down, R.E., Lafont, R., Webster, S.G., 2018. Functional Characterization and Signaling Systems of Corazonin and Red Pigment Concentrating Hormone in the Green Shore Crab, Carcinus maenas. Front. Neurosci. 11. https://doi.org/10.3389/fnins.2017.00752

Aquiloni, L., Giulianini, P.G., Mosco, A., Guarnaccia, C., Ferrero, E., Gherardi, F., 2012. Crustacean Hyperglycemic Hormone (cHH) as a Modulator of Aggression in Crustacean Decapods. PLoS One 7. https://doi.org/10.1371/journal.pone.0050047

Barry, M.J., 2018. Effects of three phamaceuticals on the responses of tadpoles to predator alarm cues: Toxicological \& Environmental Chemistry: Vol 100, No 2.

Barry, M.J., 2013. Effects of fluoxetine on the swimming and behavioural responses of the Arabian killifish. Ecotoxicology 22, 425-432. https://doi.org/10.1007/s10646-0121036-7

Barthe, J.Y., Mons, N., Cattaert, D., Geffard, M., Clarac, F., 1989. Dopamine and motor activity in the lobster Homarus gammarus. Brain Research 497, 368-373. https://doi.org/10.1016/0006-8993(89)90282-5

Benjamini, Y., Hochberg, Y., 1995. Controlling the False Discovery Rate: A Practical and Powerful Approach to Multiple Testing. Journal of the Royal Statistical Society: Series B (Methodological) 57, 289-300. https://doi.org/10.1111/j.25176161.1995.tb02031.x

Bian, X., Elgar, M.A., Peters, R.A., 2016. The swaying behavior of Extatosoma tiaratum: motion camouflage in a stick insect? Behav Ecol 27, 83-92. https://doi.org/10.1093/beheco/arv125

Bidel, F., Di Poi, C., Budzinski, H., Pardon, P., Callewaert, W., Arini, A., Basu, N., Dickel, L., Bellanger, C., Jozet-Alves, C., 2016a. The antidepressant venlafaxine may act as a neurodevelopmental toxicant in cuttlefish (Sepia officinalis). NeuroToxicology 55, 142-153. https://doi.org/10.1016/j.neuro.2016.05.023

Bidel, F., Poi, C.D., Imarazene, B., Koueta, N., Budzinski, H., Delft, P.V., Bellanger, C., JozetAlves, C., 2016b. Pre-hatching fluoxetine-induced neurochemical, neurodevelopmental, and immunological changes in newly hatched cuttlefish. Environ Sci Pollut Res 23, 5030-5045. https://doi.org/10.1007/s11356-015-45917

Bisesi, J.H., Bridges, W., Klaine, S.J., 2014. Reprint of: Effects of the antidepressant venlafaxine on fish brain serotonin and predation behavior. Aquatic Toxicology, Antidepressants in the Aquatic Environment 151, 88-96. https://doi.org/10.1016/j.aquatox.2014.02.015

Bisesi, J.H., Sweet, L.E., Hurk, P. van den, Klaine, S.J., 2016. Effects of an antidepressant mixture on the brain serotonin and predation behavior of hybrid striped bass. Environmental Toxicology and Chemistry 35, 938-945. https://doi.org/10.1002/etc.3114

Bossus, M.C., Guler, Y.Z., Short, S.J., Morrison, E.R., Ford, A.T., 2014. Behavioural and transcriptional changes in the amphipod Echinogammarus marinus exposed to two antidepressants, fluoxetine and sertraline. Aquatic Toxicology, Antidepressants in the Aquatic Environment 151, 46-56. https://doi.org/10.1016/j.aquatox.2013.11.025 
Brodin, T., Piovano, S., Fick, J., Klaminder, J., Heynen, M., Jonsson, M., 2014. Ecological effects of pharmaceuticals in aquatic systems -impacts through behavioural alterations. Philosophical Transactions of the Royal Society B: Biological Sciences 369, 20130580. https://doi.org/10.1098/rstb.2013.0580

Broekkamp, C.L.E., Leysen, D., Peeters, B.W.M.M., Pinder, R.M., 1995. Prospects for Improved Antidepressants. J. Med. Chem. 38, 4615-4633. https://doi.org/10.1021/jm00023a001

Bueno, M.J.M., Gomez, M.J., Herrera, S., Hernando, M.D., Agüera, A., Fernández-Alba, A.R., 2012. Occurrence and persistence of organic emerging contaminants and priority pollutants in five sewage treatment plants of Spain: Two years pilot survey monitoring. Environmental Pollution 164, 267-273. https://doi.org/10.1016/j.envpol.2012.01.038

Campos, B., Rivetti, C., Kress, T., Barata, C., Dircksen, H., 2016. Depressing Antidepressant: Fluoxetine Affects Serotonin Neurons Causing Adverse Reproductive Responses in Daphnia magna. Environ. Sci. Technol. 50, 6000-6007. https://doi.org/10.1021/acs.est.6b00826

Caro, T., 2005. Antipredator Defenses in Birds and Mammals. University of Chicago Press. Chabenat, A., Bellanger, C., Jozet-Alves, C., Knigge, T., 2019. Hidden in the sand: Alteration of burying behaviour in shore crabs and cuttlefish by antidepressant exposure. Ecotoxicology and Environmental Safety 186, 109738. https://doi.org/10.1016/j.ecoenv.2019.109738

Christie, A.E., Stemmler, E.A., Dickinson, P.S., 2010. Crustacean neuropeptides. Cell. Mol. Life Sci. 67, 4135-4169. https://doi.org/10.1007/s00018-010-0482-8

De Castro-Català, N., Muñoz, I., Riera, J.L., Ford, A.T., 2017. Evidence of low dose effects of the antidepressant fluoxetine and the fungicide prochloraz on the behavior of the keystone freshwater invertebrate Gammarus pulex. Environmental Pollution 231, 406-414. https://doi.org/10.1016/j.envpol.2017.07.088

De Lange, H.J., Noordoven, W., Murk, A.J., Lürling, M., Peeters, E.T.H.M., 2006. Behavioural responses of Gammarus pulex (Crustacea, Amphipoda) to low concentrations of pharmaceuticals. Aquatic Toxicology 78, 209-216. https://doi.org/10.1016/j.aquatox.2006.03.002

Detto, T., Hemmi, J.M., Backwell, P.R.Y., 2008. Colouration and Colour Changes of the Fiddler Crab, Uca capricornis: A Descriptive Study. PLOS ONE 3, e1629. https://doi.org/10.1371/journal.pone.0001629

Di Poi, C., Bidel, F., Dickel, L., Bellanger, C., 2014. Cryptic and biochemical responses of young cuttlefish Sepia officinalis exposed to environmentally relevant concentrations of fluoxetine. Aquatic Toxicology, Antidepressants in the Aquatic Environment 151, 36-45. https://doi.org/10.1016/j.aquatox.2013.12.026

Di Poi, C., Darmaillacq, A.-S., Dickel, L., Boulouard, M., Bellanger, C., 2013. Effects of perinatal exposure to waterborne fluoxetine on memory processing in the cuttlefish Sepia officinalis. Aquatic Toxicology 132-133, 84-91. https://doi.org/10.1016/j.aquatox.2013.02.004

Dircksen, H., 2013. Crustacean bioactive peptides. Academic Press Elsevier, pp. 209-221. Fingerman, M., 1985. The Physiology and Pharmacology of Crustacean Chromatophores. Integr Comp Biol 25, 233-252. https://doi.org/10.1093/icb/25.1.233 
Fingerman, M., 1965. Chromatophores. Physiological Reviews 45, 296-339. https://doi.org/10.1152/physrev.1965.45.2.296

Fingerman, M., Hanumante, M.M., Fingerman, S.W., 1981. The effects of biogenic amines on color changes of the fiddler crab, Uca pugilator: Further evidence for roles of 5hydroxytryptamine and dopamine as neurotransmitters triggering release of erythrophorotropic hormones. Comparative Biochemistry and Physiology Part C: Comparative Pharmacology 68, 205-211. https://doi.org/10.1016/03064492(81)90017-4

Fingerman, M., Jackson, N.C., Nagabhushanam, R., 1998. Hormonally-regulated functions in crustaceans as biomarkers of environmental pollution. Comparative Biochemistry and Physiology Part C: Pharmacology, Toxicology and Endocrinology 120, 343-350. https://doi.org/10.1016/S0742-8413(98)10072-5

Fong, P.P., Bury, T.B., Dworkin-Brodsky, A.D., Jasion, C.M., Kell, R.C., 2015. The antidepressants venlafaxine ("Effexor") and fluoxetine ("Prozac") produce different effects on locomotion in two species of marine snail, the oyster drill (Urosalpinx cinerea) and the starsnail (Lithopoma americanum). Marine Environmental Research 103, 89-94. https://doi.org/10.1016/j.marenvres.2014.11.010

Fong, P.P., Ford, A.T., 2014. The biological effects of antidepressants on the molluscs and crustaceans: A review. Aquatic Toxicology, Antidepressants in the Aquatic Environment 151, 4-13. https://doi.org/10.1016/j.aquatox.2013.12.003

Ford, A.T., Feuerhelm, E., 2020. Effects of the antidepressant fluoxetine on pigment dispersion in chromatophores of the common sand shrimp, Crangon crangon: repeated experiments paint an inconclusive picture. Ecotoxicology. https://doi.org/10.1007/s10646-020-02272-7

Fossat, P., Bacqué-Cazenave, J., Deurwaerdère, P.D., Delbecque, J.-P., Cattaert, D., 2014. Anxiety-like behavior in crayfish is controlled by serotonin. Science 344, 1293-1297. https://doi.org/10.1126/science.1248811

Fuhrmann, M.M., Nygård, H., Krapp, R.H., Berge, J., Werner, I., 2011. The adaptive significance of chromatophores in the Arctic under-ice amphipod Apherusa glacialis. Polar Biol 34, 823-832. https://doi.org/10.1007/s00300-010-0938-1

Gonzalez-Rey, M., Tapie, N., Le Menach, K., Dévier, M.-H., Budzinski, H., Bebianno, M.J., 2015. Occurrence of pharmaceutical compounds and pesticides in aquatic systems. Marine Pollution Bulletin 96, 384-400. https://doi.org/10.1016/j.marpolbul.2015.04.029

Hamilton, T.J., Kwan, G.T., Gallup, J., Tresguerres, M., 2016. Acute fluoxetine exposure alters crab anxiety-like behaviour, but not aggressiveness. Scientific Reports 6, 19850. https://doi.org/10.1038/srep19850

Hanumante, M.M., Fingerman, M., 1983. Effects of monoamines and monoaminergic agents on migration of the red pigment in chromatophores of the shrimp, Macrobrachium ohione. Comparative Biochemistry and Physiology Part C: Comparative Pharmacology 74, 303-309. https://doi.org/10.1016/0742-8413(83)90105-6

Hanumante, M.M., Fingerman, M., 1982a. Roles of 5-hydroxytryptamine and dopamine as neurotransmitters eliciting release of erythrophorotropic hormones in the fiddler crab, Uca pugilator. Life Sciences 31, 2667-2672. https://doi.org/10.1016/00243205(82)90710-X

Hanumante, M.M., Fingerman, M., 1982b. Further evidence for norepinephrine as a neurotransmitter stimulating release of melanin-dispersing hormone in the fiddler 
crab, Uca pugilator: the changes in the melanophores of the crabs following reserpine, 6-hydroxydopamine and bretylium administration. Gen Pharmacol 13, 99-103. https://doi.org/10.1016/0306-3623(82)90063-5

Hanumante, M.M., Fingerman, M., 1981. 5-Hydroxytryptaminergic control of red pigmentdispersing hormone release in the fiddler crab, Uca pugilator: Effects of a 5hydroxytryptamine uptake inhibitor and a 5-hydroxytryptamine receptor blocker on 5-hydroxytryptamine-induced and iproniazid-induced red pigment dispersion. General and Comparative Endocrinology 45, 395-401. https://doi.org/10.1016/0016-6480(81)90080-0

Harris-Warrick, R.M., 2011. Neuromodulation and flexibility in Central Pattern Generator networks. Current Opinion in Neurobiology, Networks, circuits and computation 21, 685-692. https://doi.org/10.1016/j.conb.2011.05.011

Jones, O.A.H., Voulvoulis, N., Lester, J.N., 2001. Human Pharmaceuticals in the Aquatic Environment a Review. Environmental Technology 22, 1383-1394. https://doi.org/10.1080/09593330.2001.11090873

Jordan, K.W., Carbone, M.A., Yamamoto, A., Morgan, T.J., Mackay, T.F., 2007. Quantitative genomics of locomotor behavior in Drosophila melanogaster. Genome Biol 8, R172. https://doi.org/10.1186/gb-2007-8-8-r172

Klosterhaus, S.L., Grace, R., Hamilton, M.C., Yee, D., 2013. Method validation and reconnaissance of pharmaceuticals, personal care products, and alkylphenols in surface waters, sediments, and mussels in an urban estuary. Environment International 54, 92-99. https://doi.org/10.1016/j.envint.2013.01.009

Kubec, J., Hossain, M.S., Grabicová, K., Randák, T., Kouba, A., Grabic, R., Roje, S., Buřič, M., 2019. Oxazepam Alters the Behavior of Crayfish at Diluted Concentrations, Venlafaxine Does Not. Water 11, 196. https://doi.org/10.3390/w11020196

Lindberg, W.J., 1980. Behavior of the Oregon Mud Crab, Hemigrapsus Oregonensis (Dana) (Brachyura, Grapsidae). Crustaceana 39, 263-281. https://doi.org/10.1163/156854080X00724

Marshall, K.L.A., Philpot, K.E., Stevens, M., 2016. Microhabitat choice in island lizards enhances camouflage against avian predators. Sci Rep 6, 1-10. https://doi.org/10.1038/srep19815

McPhee, M.J., Wilkens, J.L., 1989. Serotonin, but not dopamine or octopamine, modifies locomotor and phototaxic behavior of the crab, Carcinus maenas. Can. J. Zool. 67, 391-393. https://doi.org/10.1139/z89-058

Meador, J.P., Yeh, A., Young, G., Gallagher, E.P., 2016. Contaminants of emerging concern in a large temperate estuary. Environmental Pollution 213, 254-267. https://doi.org/10.1016/j.envpol.2016.01.088

Mennigen, J.A., Sassine, J., Trudeau, V.L., Moon, T.W., 2010. Waterborne fluoxetine disrupts feeding and energy metabolism in the goldfish Carassius auratus. Aquatic Toxicology 100, 128-137. https://doi.org/10.1016/j.aquatox.2010.07.022

Merilaita, S., Scott-Samuel, N.E., Cuthill, I.C., 2017. How camouflage works. Philosophical Transactions of the Royal Society B: Biological Sciences 372, 20160341. https://doi.org/10.1098/rstb.2016.0341

Mesquita, S.R., Guilhermino, L., Guimarães, L., 2011. Biochemical and locomotor responses of Carcinus maenas exposed to the serotonin reuptake inhibitor fluoxetine. Chemosphere 85, 967-976. https://doi.org/10.1016/j.chemosphere.2011.06.067 
Metcalfe, C.D., Chu, S., Judt, C., Li, H., Oakes, K.D., Servos, M.R., Andrews, D.M., 2010. Antidepressants and their metabolites in municipal wastewater, and downstream exposure in an urban watershed. Environmental Toxicology and Chemistry 29, 7989. https://doi.org/10.1002/etc.27

Mezzelani, M., Gorbi, S., Regoli, F., 2018. Pharmaceuticals in the aquatic environments: Evidence of emerged threat and future challenges for marine organisms. Marine Environmental Research 140, 41-60. https://doi.org/10.1016/j.marenvres.2018.05.001

Minguez, L., Pedelucq, J., Farcy, E., Ballandonne, C., Budzinski, H., Halm-Lemeille, M.-P., 2016. Toxicities of 48 pharmaceuticals and their freshwater and marine environmental assessment in northwestern France. Environ Sci Pollut Res 23, 4992-5001. https://doi.org/10.1007/s11356-014-3662-5

Morris, S., Postel, U., Mrinalini, Turner, L.M., Palmer, J., Webster, S.G., 2010. The adaptive significance of crustacean hyperglycaemic hormone (CHH) in daily and seasonal migratory activities of the Christmas Island red crab Gecarcoidea natalis. J. Exp. Biol. 213, 3062-3073. https://doi.org/10.1242/jeb.045153

Naylor, E., 1985. Tidally rhythmic behaviour of marine animals. Symp. Soc. Exp. Biol. 39, 63-93.

Nery, L.E.M., Castrucci, A.M.L., 2002. Crustacean Chromatophore: Endocrine Regulation and Intracellular Signalling Systems, in: Wiese, K. (Ed.), The Crustacean Nervous System. Springer, Berlin, Heidelberg, pp. 98-112. https://doi.org/10.1007/978-3-66204843-6_7

Nery, L.E.M., Silva, M.A.D., Castrucci, A.M.D.L., 1999. Possible role of non-classical chromatophorotropins on the regulation of the Crustacean Erythrophore. Journal of Experimental Zoology 284, 711-716. https://doi.org/10.1002/(SICI)1097010X(19991101)284:6<711::AID-JEZ13>3.0.C0;2-\#

OECD Health Statistics 2019 - OECD [WWW Document], n.d. URL http://www.oecd.org/els/health-systems/health-data.htm (accessed 2.14.20).

Paíga, P., Santos, L.H.M.L.M., Ramos, S., Jorge, S., Silva, J.G., Delerue-Matos, C., 2016. Presence of pharmaceuticals in the Lis river (Portugal): Sources, fate and seasonal variation. Science of The Total Environment 573, 164-177. https://doi.org/10.1016/j.scitotenv.2016.08.089

Painter, M.M., Buerkley, M.A., Julius, M.L., Vajda, A.M., Norris, D.O., Barber, L.B., Furlong, E.T., Schultz, M.M., Schoenfuss, H.L., 2009. Antidepressants at environmentally relevant concentrations affect predator avoidance behavior of larval fathead minnows (Pimephales promelas). Environmental Toxicology and Chemistry 28, 2677-2684. https://doi.org/10.1897/08-556.1

Pavlova, G.A., 2001. Effects of serotonin, dopamine and ergometrine on locomotion in the pulmonate mollusc Helix lucorum. Journal of Experimental Biology 204, 1625-1633.

Peeke, H.V.S., Blank, G.S., Figler, M.H., Chang, E.S., 2000. Effects of exogenous serotonin on a motor behavior and shelter competition in juvenile lobsters (Homarus americanus). J Comp Physiol A 186, 575-582. https://doi.org/10.1007/s003590000113

Peters, J.R., Granek, E.F., Rivera, C.E. de, Rollins, M., 2017. Prozac in the water: Chronic fluoxetine exposure and predation risk interact to shape behaviors in an estuarine crab. Ecology and Evolution 7, 9151-9161. https://doi.org/10.1002/ece3.3453 
Porras, M.G., De Loof, A., Breuer, M., Aréchiga, H., 2003. Corazonin promotes tegumentary pigment migration in the crayfish Procambarus clarkii. Peptides, Invertebrate Neuropeptides IV 24, 1581-1589. https://doi.org/10.1016/j.peptides.2003.08.016

Powell, B.L., 1962a. The Responses of the Chromatophores of Carcinus Maenas (L., 1758) To Light and Temperature. Crustaceana 4, 93-102. https://doi.org/10.1163/156854062X00120

Powell, B.L., 1962b. Types, Distribution and Rhythmical Behaviour of the Chromatophores of Juvenile Carcinus maenas (L.). Journal of Animal Ecology 31, 251-261. https://doi.org/10.2307/2139

Rao, K.R., 2001. Crustacean Pigmentary-Effector Hormones: Chemistry and Functions of RPCH, PDH, and Related Peptides. Integr Comp Biol 41, 364-379. https://doi.org/10.1093/icb/41.3.364

Rao, K.R., Fingerman, M., 1970. Action of biogenic amines on crustacean chromatophores: I. Differential effect of certain indolealkylamines on the melanophores of the crabsUca pugilator andCarcinus maenas. Experientia 26, 383-384. https://doi.org/10.1007/BF01896901

Robert, A., Monsinjon, T., Delbecque, J.-P., Olivier, S., Poret, A., Foll, F.L., Durand, F., Knigge, T., 2016. Neuroendocrine disruption in the shore crab Carcinus maenas: Effects of serotonin and fluoxetine on chh- and mih-gene expression, glycaemia and ecdysteroid levels. Aquatic Toxicology 175, 192-204. https://doi.org/10.1016/j.aquatox.2016.03.025

Robert, A., Schultz, I.R., Hucher, N., Monsinjon, T., Knigge, T., 2017. Toxicokinetics, disposition and metabolism of fluoxetine in crabs. Chemosphere 186, 958-967. https://doi.org/10.1016/j.chemosphere.2017.08.018

Rúa-Gómez, P.C., Püttmann, W., 2012. Occurrence and removal of lidocaine, tramadol, venlafaxine, and their metabolites in German wastewater treatment plants. Environ Sci Pollut Res 19, 689-699. https://doi.org/10.1007/s11356-011-0614-1

Schlüsener, M.P., Hardenbicker, P., Nilson, E., Schulz, M., Viergutz, C., Ternes, T.A., 2015. Occurrence of venlafaxine, other antidepressants and selected metabolites in the Rhine catchment in the face of climate change. Environmental Pollution 196, 247256. https://doi.org/10.1016/j.envpol.2014.09.019

Siegenthaler, A., Mastin, A., Dufaut, C., Mondal, D., Benvenuto, C., 2018. Background matching in the brown shrimp Crangon crangon: adaptive camouflage and behavioural-plasticity. Sci Rep 8, 1-12. https://doi.org/10.1038/s41598-01821412-y

Stevens, M., 2016. Color Change, Phenotypic Plasticity, and Camouflage. Front. Ecol. Evol. 4. https://doi.org/10.3389/fevo.2016.00051

Stevens, M., Lown, A.E., Wood, L.E., 2014a. Color change and camouflage in juvenile shore crabs Carcinus maenas. Front. Ecol. Evol. 2. https://doi.org/10.3389/fevo.2014.00014

Stevens, M., Lown, A.E., Wood, L.E., 2014b. Camouflage and Individual Variation in Shore Crabs (Carcinus maenas) from Different Habitats. PLOS ONE 9, e115586. https://doi.org/10.1371/journal.pone.0115586

Stevens, M., Ruxton, G.D., 2019. The key role of behaviour in animal camouflage. Biological Reviews 94, 116-134. https://doi.org/10.1111/brv.12438 
Strauss, J., Dircksen, H., 2010. Circadian clocks in crustaceans: identified neuronal and cellular systems. Frontiers in Bioscience 15, 1040-1074.

Sugimoto, M., 2002. Morphological color changes in fish: Regulation of pigment cell density and morphology. Microscopy Research and Technique 58, 496-503. https://doi.org/10.1002/jemt.10168

Sumpter, J.P., Donnachie, R.L., Johnson, A.C., 2014. The apparently very variable potency of the anti-depressant fluoxetine. Aquatic Toxicology, Antidepressants in the Aquatic Environment 151, 57-60. https://doi.org/10.1016/j.aquatox.2013.12.010

Thompson, W.A., Arnold, V.I., Vijayan, M.M., 2017. Venlafaxine in Embryos Stimulates Neurogenesis and Disrupts Larval Behavior in Zebrafish. Environ. Sci. Technol. 51, 12889-12897. https://doi.org/10.1021/acs.est.7b04099

Tierney, A., Mangiamele, L., 2001. Effects of serotonin and serotonin analogs on posture and agonistic behavior in crayfish. J Comp Physiol A 187, 757-767. https://doi.org/10.1007/s00359-001-0246-x

Tierney, A.J., Hanzlik, K.N., Hathaway, R.M., Powers, C., Roy, M., 2016. Effects of fluoxetine on growth and behavior in the crayfish Orconectes rusticus. Marine and Freshwater Behaviour and Physiology 49, 133-145. https://doi.org/10.1080/10236244.2015.1119974

Tyrie, E.K., Hanlon, R.T., Siemann, L.A., Uyarra, M.C., 2015. Coral reef flounders, Bothus lunatus, choose substrates on which they can achieve camouflage with their limited body pattern repertoire. Biol J Linn Soc 114, 629-638. https://doi.org/10.1111/bij.12442

Umbers, K.D.L., Fabricant, S.A., Gawryszewski, F.M., Seago, A.E., Herberstein, M.E., 2014. Reversible colour change in Arthropoda. Biological Reviews 89, 820-848. https://doi.org/10.1111/brv.12079

Webb, H.M., 1983. Persistent rhythms of decapod crustaceans. Studies in Adaptation: the Behavior of Higher Crustacea.

Williams, B.G., Naylor, E., 1969. Synchronization of the Locomotor Tidal Rhythm of Carcinus. Journal of Experimental Biology 51, 715-725.

Williams, J.A., Pullin, R.S.V., Williams, B.G., Aréchiga, H., Naylor, E., 1979. Evaluation of the effects of injected eyestalk extract on rhythmic locomotor activity in Carcinus. Comparative Biochemistry and Physiology Part A: Physiology 62, 903-907. https://doi.org/10.1016/0300-9629(79)90026-4 